\title{
Insular Carnivore Biogeography: Island Area and Mammalian Optimal Body Size
}

Shai Meiri, ${ }^{1, *}$ Daniel Simberloff, ${ }^{2, \dagger}$ and Tamar Dayan ${ }^{1, \star}$

1. Department of Zoology, Tel Aviv University, Tel Aviv 69978, Israel;

2. Department of Ecology and Evolutionary Biology, University of Tennessee, Knoxville, Tennessee 37996

Submitted June 9, 2004; Accepted December 14, 2004;

Electronically published March 8, 2005

Online enhancement: appendix tables.

ABSTRACT: Patterns of size variation in insular mammals have been used to support the claim that mammals have a single optimal body size. This hypothesis enjoys wide support, despite having been questioned on both theoretical and empirical grounds. It is claimed that species of optimal size maintain the highest population densities. Therefore these species are thought to inhabit the smallest islands, where larger and smaller species are generally absent. We sought such a pattern by testing how area affects the body sizes of the largest and smallest carnivore species on islands. Using data on carnivores from 322 islands, we found that the sizes of carnivores on small islands tend to be close to the order's mode. Furthermore, we found that the size distribution of carnivore species that inhabit islands resembles that of those whose range is entirely continental. We conclude that insular carnivores provide no support for theories proposing a single optimal size, and we suspect such theories are also flawed on theoretical grounds.

Keywords: Carnivora, islands, island area, optimal body size.

Mammals come in many sizes, from 2-g shrews and bats to blue whales (Balaenoptera musculus) nearly six orders of magnitude larger (Nowak 1999). However, not all sizes are equally common. The frequency distribution of mammalian body sizes is highly skewed, with a conspicuous mode in the small size range at about $25 \mathrm{~g}$ (Gardezi and da Silva 1999). Although other lower peaks are found at

\footnotetext{
* Corresponding author; e-mail: uncshai@post.tau.ac.il.

† E-mail: dsimberloff@utk.edu.

₹ E-mail: dayant@post.tau.ac.il.
}

Am. Nat. 2005. Vol. 165, pp. 505-514. (c) 2005 by The University of Chicago. 0003-0147/2005/16504-40480\$15.00. All rights reserved. higher masses (Bourliere 1975; Alroy 1998, 2003; Lovegrove and Haines 2004), there is no denying that there are more species of fairly small mammals than there are species of either larger or smaller ones (Blackburn and Gaston 1998; Smith et al. 2004).

A similarly shaped size distribution for animals in general (Blackburn and Gaston 1994; Purvis et al. 2003) led Hutchinson and MacArthur (1959) to try to explain the abundance of small animals by claiming that such species perceive the environment as coarser grained compared with the perception of larger ones, thus enabling them to occupy more niches. Stanley (1973) stressed the importance of constraints on minimum size to account for the scarcity of species in the very smallest size classes. At the same time, he argued against a misleading interpretation of Cope's rule, according to which larger is always better. According to Stanley (1973), the abundance of relatively small species is a consequence of higher rates of speciation at these sizes. He concluded that the disadvantages of increased size, that is, the higher risk of extinction, cause the observed pattern. Gould (1988) likewise emphasized the existence of a stable modal body size throughout the history of various clades.

Maiorana (1990) suggested that the modal size is adaptive in itself. She claimed that an intermediate size may be optimal for obtaining and processing energy as well as for allocating the largest proportion of energy to reproduction. Maiorana (1990) attributed deviations from the modal size to competition and predation and suggested that lower levels of both selective pressures on islands may explain the tendency of insular mammals to converge on an intermediate size (Van Valen 1973; Lomolino 1985; but see Meiri et al. 2004a). Damuth (1993) also claimed that intermediate masses are optimal, and he explicitly defined what this optimum mass is: $1,000 \mathrm{~g}$. He maintained that the optimal size is the size at which species are able to control the greatest proportion of available energy. Damuth (1993) found that in guilds of mostly small mammals (the largest members of which weigh about $1 \mathrm{~kg}$ ), it is the larger species that control most energy. However, it is small members that control most of the energy in guilds of 
mostly large mammals (guilds where the smaller species weigh about $1 \mathrm{~kg}$ ). Damuth (1993) therefore concluded that it is at about $1 \mathrm{~kg}$ that species control most energy in most dietary groups.

That same year, Brown and his colleagues also claimed the existence of an optimal intermediate size of terrestrial mammals at $100 \mathrm{~g}$ (Brown et al. 1993), arguing that this value is close to the mammalian modal size. Brown et al. (1993) suggested that mammals of about $100 \mathrm{~g}$ are most efficient in converting energy into offspring production and that the modal size is a consequence of the higher fitness of optimal-sized mammals. Brown et al. (1996, p. 1073) proposed that their model predicts the optimal size for a clade in the absence of resource limitation.

Both Damuth (1993) and Brown et al. (1993) saw their conclusion - a single optimal body size for all terrestrial mammals - as supported by the size patterns of insular mammals (e.g., Foster 1964; Lomolino 1985). However, resource limitation is thought by some to be of major importance for size evolution on islands (Heaney 1978; Lomolino 1985); if true, this would be at odds with one of the model's assumptions (Brown et al. 1996). Brown et al. (1993) and Damuth (1993) argued that competition causes deviations from optimal size and that reduced competition on islands leads to evolution toward the optimal size there. Maurer et al. (1992) suggested that $250 \mathrm{~g}$ is approximately the body mass at which, according to Lomolino's (1985) data, island forms tend not to diverge from their mainland relatives. Brown et al. (1993) suggested that the similarity of $250 \mathrm{~g}$ to $100 \mathrm{~g}$ lends empirical support to their model (but see Blackburn and Gaston 1996; Meiri et al. 2004a).

Another study believed to support this model is that of Marquet and Taper (1998, cited as an unpublished manuscript by Brown et al. [1993]). These authors regressed the logarithm of island area on the logarithms of the sizes of both the largest and the smallest mammals in mountaintop "islands" in the American Southwest, on landbridge islands in the Sea of Cortéz, and on seven continents (Marquet and Taper 1998). They found that the two regression lines intersect at 1.71 (Marquet and Taper 1998), corresponding to a mass of $51 \mathrm{~g}$ (Meiri et al. 2004a). Boback and Guyer (2003), analyzing a sample of insular snakes, found qualitatively similar regression lines, converging at a size very similar to the one actually found on one-species islands. Theoretically, the convergence is predicted by the species-area relationship, because drawing a larger number of species at random from the regional species pool will result in a wider size range on larger islands (Blackburn and Gaston 1996). Marquet and Taper (1998) performed a bootstrap analysis, showing that slopes predicted from such a random process are significantly steeper than those actually observed, with the lines intersecting at about $100 \mathrm{~g}$ rather than the observed $50 \mathrm{~g}$.

Kelt and Van Vuren $(1999,2001)$ advanced another line of evidence in support of an optimal size at about $100 \mathrm{~g}$; they found that the minimum mammalian home ranges decrease with mass up to about $100 \mathrm{~g}$ and increase as mass increases beyond this point. Marquet and Taper (1998) assert that it is this tendency of 100 -g mammals to have the smallest ranges that is adaptive. They suggested that, as population size is inversely correlated with extinction probability, the smaller the geographical area inhabited by a population, the more likely it is to go extinct. Citing these data and those of Brown and Maurer (1989), Marquet and Taper (1998) predicted that, on the smallest islands, only mammals close to the optimal size (i.e., those with the smallest home range) will persist. Wassersug et al. (1979) accounted for the evolution of insular dwarves by a similar argument.

According to these theories, the course of evolution can go either way, but populations evolving toward the "wrong" size are more likely to go extinct (Roth 1992; but see Wilkinson and O'Regan 2003 for an example where a larger species further away from the optimum is more likely to persist on small islands). The only additional test using Marquet and Taper's (1998) logic, conducted by Burness et al. (2001), supported their conclusion regarding the relationship between home range and island area, at least for the largest species.

Despite much criticism, the notion of a single body mass optimum for a given taxon still enjoys a respectable reputation in recent works (e.g., Ginsberg 2000; Roy et al. 2000; Boback and Guyer 2003; Clarke 2003; Raia et al. 2003; Scott et al. 2003; Etienne and Olff 2004). This may be due to its apparent success in using simple physiological allometries to predict evolutionary and ecological phenomena such as modal body sizes and the direction of size evolution on islands (see also Blackburn and Gaston 1994). Empirical support for the two models (Brown et al. 1993; Damuth 1993) was found in patterns of size evolution on islands at both the intra- (Lomolino 1985) and interspecific levels (Marquet and Taper 1998).

At the intraspecific level, we have shown (Meiri et al. $2004 a$ ) that the model is not supported. We now aim to test predictions stemming from the interspecific pattern described by Marquet and Taper (1998). We ask if carnivore species tend to approach a particular size on small islands or if the size of carnivores on the smallest islands can be predicted by a random draw from the appropriate species pool. Carnivores are suitable for such a study because they are extremely diverse in size, social structure, diet, and other life-history characteristics (Gittleman 1985; Macdonald 1992; Gittleman and Van Valkenburgh 1997; Nowak 1999; Kruuk 2002), making them an adequate 
model for mammals as a whole, despite a minority of species smaller than $100 \mathrm{~g}$. That this size is within the range of carnivore sizes makes this clade appropriate for such a study, in that the model predicts that species in this size class will be relatively more abundant on islands than if species were drawn randomly from a global pool, with the number of species drawn for each site the number actually present at that site. Insular carnivores inhabit continental-shelf islands almost exclusively (Alcover and McMinn 1994), thus forming precisely the type of relaxation faunas predicted to show the pattern reported by Marquet and Taper (1998).

\section{Material and Methods \\ Carnivore Biogeography}

For each island on which carnivores occur naturally, we recorded island area and carnivore richness. We obtained data on island areas from the literature (e.g., Lawlor 1982; Heaney 1986), from the United Nations Environment Programme Web site (http://islands.unep.ch/isldir.htm), and from E. Meijaard and J. Calder (personal communication, 2003). In other cases, island area was obtained from a computerized Geographic Information Systems map of the world.

We compiled data on carnivore occurrence on islands from museum specimens and from the literature. Carnivore species said to occupy an island by any source were counted as present, unless specifically marked as absent by another source. We followed the taxonomy of Nowak (1999) and excluded marine species (Enhydra lutris, Ursus maritimus). We disregarded all known cases of historic introductions but did use data on species whose status as introduced is difficult to establish (e.g., the five strictly insular species of raccoons: Procyon, Zeveloff 2003; viverrids east of Wallace's line: e.g., Paradoxurus hermaphroditus, Meijaard 2003). Carnivores known to have gone extinct on an island during historic times were counted as extant (e.g., Ursus arctos on Britain; Yalden 1999). Because of uncertainties as to the extent of carnivore movement over sea ice in northern latitudes, we limited our analysis to islands south of the Arctic Circle.

\section{Body Mass}

We compiled a list of the masses of all wild terrestrial carnivores (table A1 in the appendix in the online edition of the American Naturalist), obtaining masses from museum specimen labels or from the literature if weight data were missing. Both these methods are flawed (see an excellent discussion in Smith and Jungers 1997), especially the latter, where sometimes the primary sources for mass data are not even acknowledged. Carnivores, more than the primates discussed by Smith and Jungers (1997), present an additional problem: geographic variation, which is often very pronounced in carnivores (Meiri et al. 2004b). Because the mass within a species of carnivore often varies more than twofold over its geographic range, we used the midpoint of the mass range as an estimate wherever possible (with museum data and with sources reporting masses of individuals; e.g., Silva and Downing 1995). The use of the midpoint avoids the problem of excessively weighting easily obtainable data. We used only wild-caught adult specimens (those with complete closure of the dorsal sutures of the skull) for calculations of masses of museum specimens. A list of individual specimen masses is available from S. Meiri. We were unable to obtain mass data for nine species. For eight of these species, we estimated mass based on body length (Silva 1998), skull length (CBL; Von den Driesch 1976), or the length of the lower carnassial (Van Valkenburgh 1990; table A1). For the ninth species, Procyon minor, we used mass of Procyon lotor from Georgia (Silva and Downing 1995) because this raccoon is similar in size to those of the southeastern United States (Helgen and Wilson 2003).

Sexual size dimorphism, with males larger than females, is pronounced in many carnivores (Gittleman and Van Valkenburgh 1997; Dayan and Simberloff 1998; Weckerly 1998). It can therefore be argued that we should use masses of females from the smallest species and of males from the largest. Mass data, however, are often missing for the separate sexes. More importantly, studies relevant to the question we ask (e.g., those that study basal metabolic rate, home range size, etc.) invariably use species-specific averages rather than female or male mass, including both models of optimal size discussed here (Brown et al. 1993; Damuth 1993) and data used to support them (Marquet and Taper 1998). Moreover, the two sexes cannot be regarded as independent data points, in either the statistical sense (Smith 1994) or the biological (home range, viable population) one. We therefore used the average of the minimum mass of the smallest sex and the maximum mass of the larger sex where such data were available. Otherwise, we averaged the mean masses of the sexes. When no mass estimate was available for both sexes, we used average species mass.

The smallest carnivores on many of the islands were Mustela erminea and Mustela nivalis. Because both these Holarctic species are usually smaller in North America than in Eurasia, we used different mass estimates for these species in Nearctic and Palearctic regions. Based on specimens we have examined, we use $41.5 \mathrm{~g}$ and $82.5 \mathrm{~g}$ as the mass of M. nivalis and $182 \mathrm{~g}$ and $264 \mathrm{~g}$ as the mass of $M$. erminea in the Nearctic and Palearctic regions, respectively. 


\section{Analysis}

We first checked if size determines whether different carnivore species are prevented from inhabiting islands. We did so by comparing the mass frequency distribution of all carnivores inhabiting at least one island to that for species that are strictly continental. If carnivores much larger than $100 \mathrm{~g}$ are at a disadvantage on islands, we predict that such species will be more likely to be excluded from the insular environment, whereas small species will be more likely to inhabit islands. To investigate whether large carnivores inhabit only large islands, whereas small carnivores can be found on both large and small islands, we regressed body mass on the area of the smallest island on which a particular species occurs.

We then determined both the largest and the smallest carnivore species occurring on each island and correlated sizes of both species with the logarithm of island area (in square kilometers). According to the physiologically based optimal body size theory (Brown et al. 1993; Marquet and Taper 1998), because most carnivores are larger than 100 g, only members of the smallest species are predicted to occur on very small islands. This model predicts that the correlation between size and area will be positive for the largest carnivore species on islands, but because the smallest carnivores are near the proposed optimal size of 100 $\mathrm{g}$, all islands regardless of their area will have as their smallest carnivore species one of the smallest carnivores in the regional assemblage. Thus, the size of the smallest carnivore should be independent of island area.

We therefore separately regressed the masses of both the smallest and largest carnivore on each island against island area. We then calculated the intersection point of these two regression lines (following Marquet and Taper 1998). The optimal size model predicts that these lines will intersect at $100 \mathrm{~g}$.

To see whether the result of this analysis differs from those expected by chance, we drew at random for each island the same number of carnivores actually occurring on it from the global species pool. We then found the largest and smallest mass of each draw and regressed both the smallest masses and the largest ones on actual island area for all islands in our sample. We then found the mass at which the two lines intersect. This procedure was repeated 10,000 times. We compared the frequency distribution of masses thus obtained to the result obtained with the real data.

\section{Results}

A frequency distribution of all sizes of all carnivore species occurring on islands (aside from introduced species) versus those never occurring on islands without human as- sistance is depicted in figure 1. The latter two distributions differ significantly from one another (KolmogorovSmirnov two-sample test, $D=0.177, P<.05)$. The average mass of insular carnivore species $(3,544 \mathrm{~g})$ is higher (i.e., farther away from $100 \mathrm{~g}$ ) than that of strictly continental ones $(2,745 \mathrm{~g})$, although this difference is only marginally significant (Mann-Whitney $U$-test, $U=6,199$, $P=.053)$. The average mass in the order is $3,159 \mathrm{~g}$. Furthermore, there is no correlation between the mass of a carnivore species and the area of the smallest island that it inhabits $(n=132, r=-0.107, P=.22)$.

The smallest and largest carnivore species on all 322 islands are listed in table $\mathrm{A} 2$ in the online edition of the American Naturalist (a list of all the carnivores occurring on each of these islands is available from S. Meiri). Figure 2 shows the correlations between the logarithm of island area (on the ordinate) and the logarithms of both the largest and the smallest carnivore masses (on the abscissa; following Marquet and Taper 1998). Both correlations are significant $(n=322$; smallest carnivores, $r=-0.226$, $P<.001$; largest carnivores, $r=0.430, P<.001)$. The equations for the linear correlation are $y=-0.301 x+$ 3.617 for the smallest carnivores and $y=0.517 x+0.641$ for the largest ones. The intersection of these two lines is at $x=3.64$, corresponding to a mass of $4,363 \mathrm{~g}$. This size is slightly higher than the order's modal size class. The two lines intersect at an area of $333 \mathrm{~km}^{2}$. Therefore, on smaller islands, carnivore mass cannot be predicted from these equations. For the 148 such islands in our database, the modal size class of the smallest carnivores is the 1,5854,000 -g one (40 islands). The modal size class of the largest carnivores in those islands is $4-10-\mathrm{kg}$ (53 islands). These two size classes, with 38 and 37 islands, respectively, are the modal mass categories for the 118 islands that have a single carnivore species.

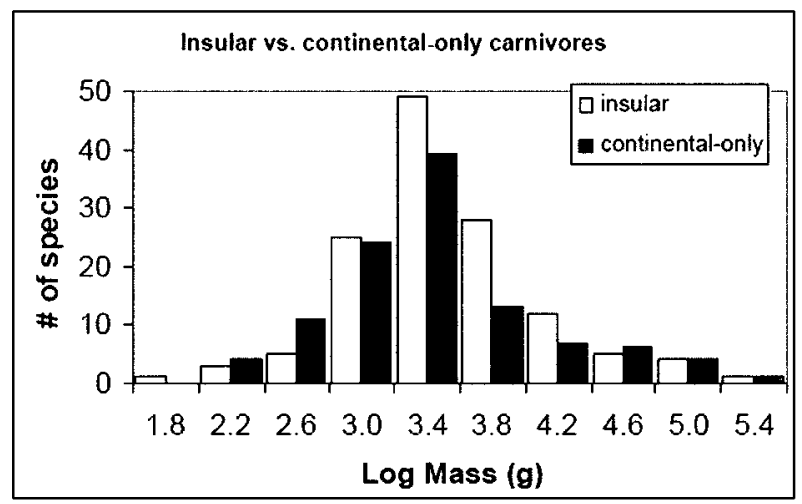

Figure 1: Mass distribution of carnivores. Shaded bars = carnivores not naturally occurring on islands. Unshaded bars = carnivores naturally occurring on islands. 


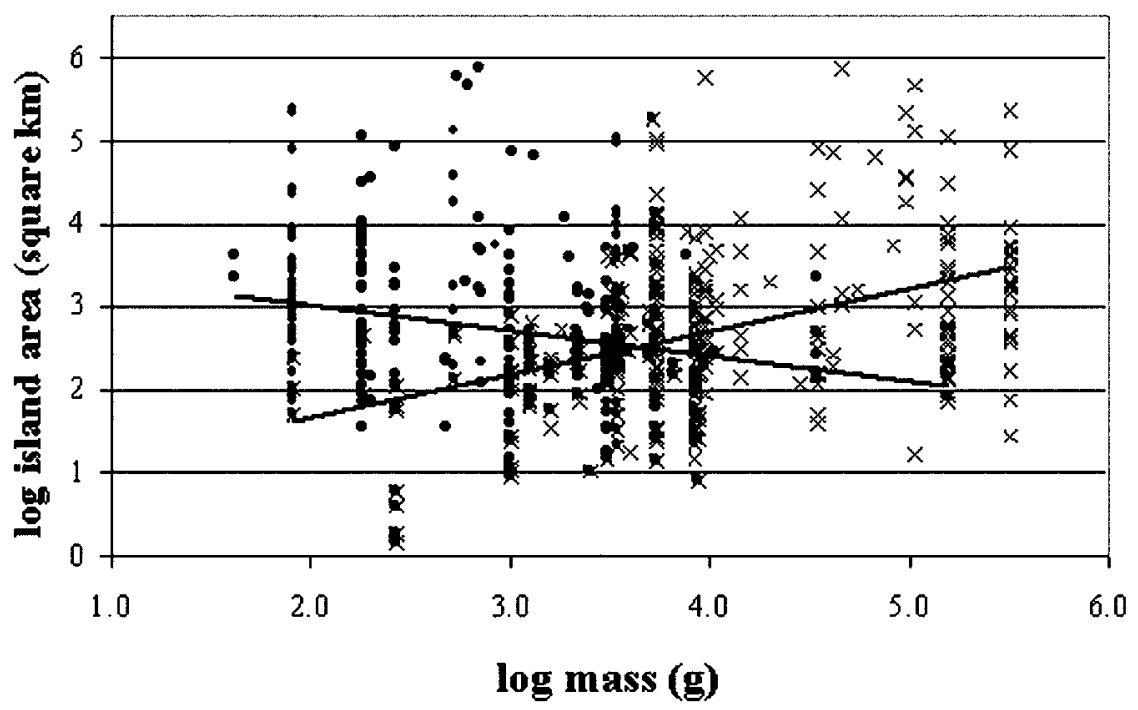

Figure 2: Correlations between the logarithm of island area (in square kilometers) and the logarithm of body mass (in grams) of the smallest and largest carnivores on all islands in table A2 in the online edition of the American Naturalist. A dot represents the smallest carnivore on each island (descending line is a product-moment correlation best-fit line). An $X$ represents the largest carnivore on each island (ascending line is a productmoment correlation best-fit line).

Both carnivore richness and size range (calculated as the ratio of the largest to the smallest carnivore masses) increase with island size: the species-area relationship is $y=0.583 x^{0.218}\left(R^{2}=0.374\right)$. The mass range increases with area as $y=0.363 x^{0.529}\left(R^{2}=0.204\right)$, and $y=$ $3.44 x^{0.342}$ when islands inhabited by only one carnivore species (i.e., those with a mass range of 1 ) are omitted.

Results of the bootstrap procedure are presented in figure 3. The mean size in 10,000 simulated runs is 3.494, corresponding to a mass of $3,122 \mathrm{~g}$. This value is lower than the size where the two correlation lines converge. None of the bootstrap values is as large as the 4,363 $\mathrm{g}$ actually obtained.

For fitted regression lines for different archipelagoes (18 archipelagoes with $n>4$ islands) separately, the average mass at which the two regression lines intersect is 20,450 g when one anomalous result (south Alaska, where the largest carnivore on all islands is Ursus arctos) is omitted. In only one archipelago (the west Mediterranean) do the regression lines intersect at a mass $(171 \mathrm{~g})$ within the range advocated in support of the model (80-250 g; see discussion in Blackburn and Gaston 1996).

\section{Discussion}

We find no evidence to support the optimal size model in our data. Species inhabiting islands are no closer to 100 $\mathrm{g}$ or $1 \mathrm{~kg}$ than are strictly continental species, and small islands are inhabited by modal-sized species rather than by species closer in mass to the proposed optima.

It seems that carnivores absent from islands are nearly always those that do not even reach the coastal areas (e.g., Felis jacobita, Mustela nigripes, Osbornictis piscivora, Panthera uncia) or, more frequently, those found in islandpoor environments (e.g., Africa, eastern South America). In our opinion, the only carnivore species we would have expected to find on islands (species that inhabit continental areas adjacent to islands on which carnivores are known to occur) but do not are probably the kit and swift foxes (Vulpes macrotis, Vulpes velox). Their masses are within the modal size category of insular carnivores (fig. 1). Therefore, we believe that carnivores are not excluded from insular environments because they are the wrong size (and indeed, the entire range of terrestrial mammal sizes, from elephants to pygmy shrews, is represented on the island of Sri Lanka; Nowak 1999).

If a body mass of $100 \mathrm{~g}$ were advantageous, we would predict that the smallest carnivore in an assemblage would be present on the smallest islands while larger species would not, because carnivores are nearly always larger than $100 \mathrm{~g}$. Therefore, as Marquet and Taper (1998) found, the regression lines should intersect near this size. In fact, the regression lines describing the relationship of the extreme sizes of carnivores and island area cross at the modal size class of the order, more than an order of magnitude larger than the predicted mass. This size is also the most common on the smallest islands, as expected if colonization were 


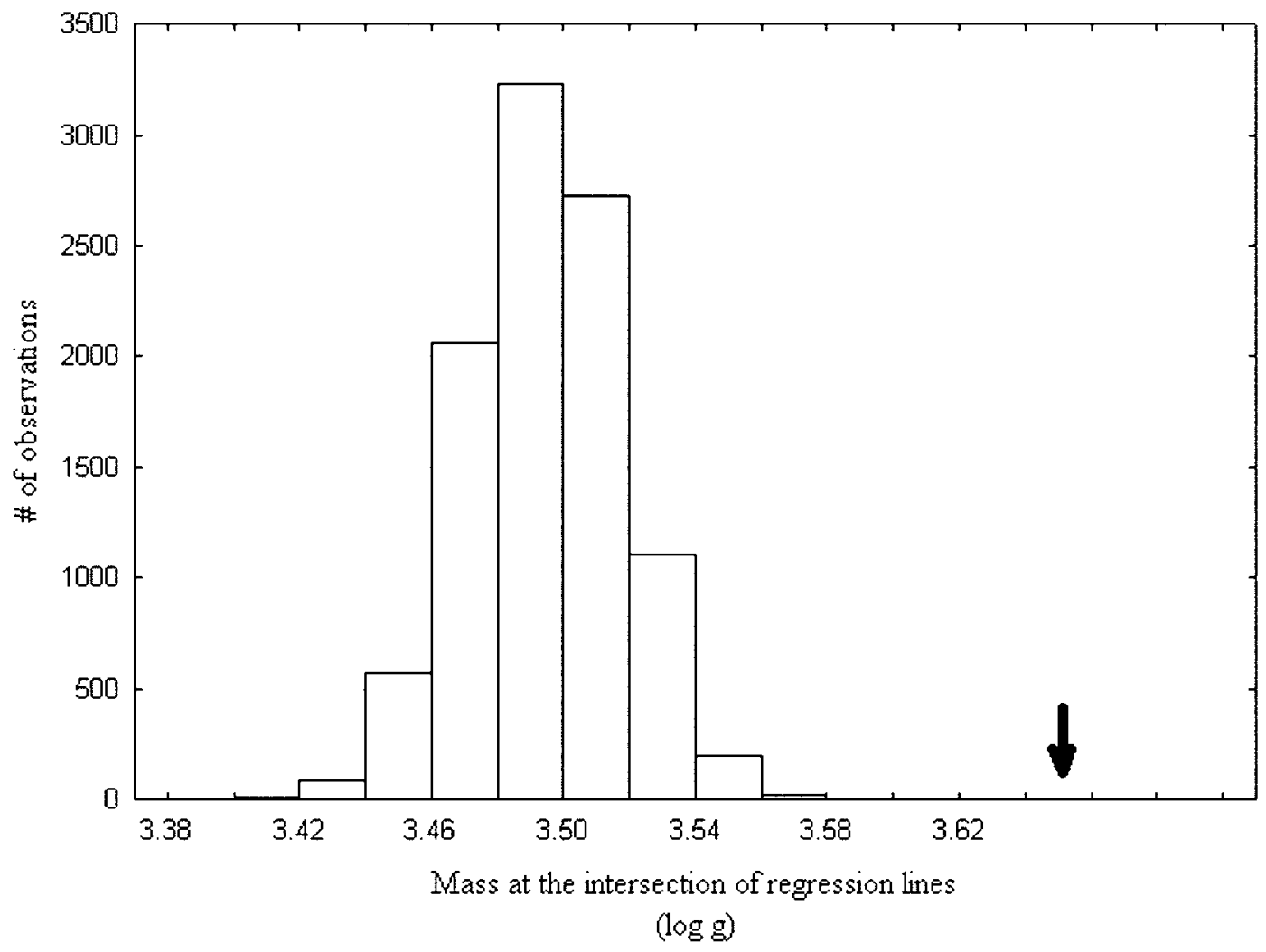

Figure 3: Results of a bootstrap analysis. The abscissa represents the logarithm of body mass (in grams) at the intersection of two correlation lines: that of $(\log )$ mass of the smallest carnivore on each island and $(\log )$ island area and that of $(\log )$ mass of the largest carnivore on each island and $(\log )$ island area. The ordinate is the frequency of such observations in a bootstrap procedure repeated 10,000 times. The arrow points to the actual value.

random in relation to size (Blackburn and Gaston 1996). Our bootstrap analysis actually implies that carnivores inhabiting small islands are significantly larger than expected by chance. The tendency of large mammals to have wide geographic distributions (Brown 1995) may explain both this result and the fact that species of carnivores that inhabit insular environments are on average larger than strictly continental ones.

Our results imply that carnivore colonization and extinction patterns on islands are to a large extent independent of size. It is not uncommon to find the largest carnivore in a regional species pool on small islands, and often the smallest carnivore (i.e., the one closest to $100 \mathrm{~g}$ ) does not inhabit such islands. While Mustela nivalis is indeed quite ubiquitous on Palearctic islands (islands near Britain notwithstanding), it is nearly always absent from Nearctic ones. In tropical areas, the smallest carnivores (e.g., Mustela lutreolina in Southeast Asia, Lyncodon patagonicus in South America, and Helogale parvula in Africa) are remarkable in their absence from small islands (the latter two are strictly continental).

The theory of a single optimal size for mammals has generated much controversy. Brown et al.'s (1993) model attracted criticism on theoretical grounds. It was claimed that the model ignores mortality and that exponents used in building it are unrealistic (Kozlowski 1996; cf. Brown et al. 1996), that it maximizes power instead of efficiency (Chown and Gaston 1997), and that it uses the wrong units, mixing reproductive output and conversion rate (Perrin 1998). It was claimed that it is internally inconsistent (Bokma 2001), that it ignores important aspects of time allocation, and that it mixes individual with population estimates (Kozlowski 2002; but see Brown et al. 1996). Blackburn and Gaston (1996) forcefully argued that different subtaxa may have different optima-that modal does not mean best. They also showed that evidence cited in support of the model actually spans a fairly wide range of sizes (see also Meiri et al. 2004a). 
Empirical analyses of life-history traits of bats (Jones and Purvis 1997) and insectivores (Symonds 1999) failed to support the model, which also failed to predict the modal body size of diprotodont marsupials (Chown and Gaston 1997). Similarly, we found no tendency for evolution toward an optimum size in insular carnivores (Meiri et al. 2004a).

Could it be that, with respect to the optimal size, carnivores differ in some way from other mammals, as do the mostly carnivorous bats and insectivores (Jones and Purvis 1997; Symonds 1999)? Marquet et al. (1995) found different allometries of population density in herbivorous, omnivorous, and carnivorous mammals (however, carnivorous and insectivorous mammals have negative allometries, suggesting that small species control the most energy). The scaling of home range for carnivorous mammals has similar slopes to those of omnivorous and herbivorous ones (Kelt and Van Vuren 2001). The higher intercepts of the former should reflect differing densities of food for these groups (McNab 1963; Kelt and Van Vuren 2001). This fact implies that carnivores may be absent from the smallest islands (Heaney 1984), not that the optimal size of carnivorous mammals should differ from that of herbivores.

The shape of the function relating home ranges to mass of carnivores is very similar to that for all mammals (data provided by D. A. Kelt), fitting an oblong polygonal area with a minimum range size at masses slightly above the minimum mass. The mass at this minimum range for carnivores (Kelt and Van Vuren 2001), however, is higher than that of all mammals, by about an order of magnitude (the smallest ranges are for the $\sim 700$-g introduced Herpestes javanicus [Nellis and Everard 1983] and the $~ 2,100-$ g Genetta tigrina [Ikeda et al. 1982]). The smallest mammalian home ranges nearly always belong to fossorial rodents of $\sim 100 \mathrm{~g}$ (Kelt and Van Vuren 1999).

Therefore, most empirical evidence for an optimal size at $100 \mathrm{~g}$ rests on the slender shoulders of rodents. Rodents of $100 \mathrm{~g}$ are extremely abundant and 100-g marsupials, insectivores, and bats fairly so (Gardezi and da Silva 1999). The latter three taxa were found not to conform to the predictions of this hypothesis (Chown and Gaston 1997; Jones and Purvis 1997; Symonds 1999). For carnivores, $100 \mathrm{~g}$ seems more like a constraint on size rather than an optimum (see discussion on the smallest carnivores in King 1989).

Within herbivorous mammals, a mass of $100 \mathrm{~g}$ is rare except in rodents. It is absent in ungulates, often limited to large sizes by the requirement for efficient fermentation of plant material in hindgut fermenters (Proboscidea, Perissodactyla) and ruminants. Marine mammals (Sirenia, Cetacea, Pinnipedia) are also uniformly large. We do not believe that it is competition with rodents that keeps these and other mammals (e.g., Xenarthra) from attaining a mass of $100 \mathrm{~g}$, but that $100 \mathrm{~g}$ is not optimal for those taxa (Blackburn and Gaston 1996), whereas the optimal size model predicts every mammalian subclade to have the same size distribution and mode (Purvis et al. 2003). Neither do we believe that our results indicate that carnivores have an optimal size of their own (be that at the modal size, modal size of insular carnivores, intersection point of the regression line, or otherwise). In this diverse assemblage, each species is probably well adapted to its particular niche.

We therefore believe that what needs to be explained is not why the 100-g class is so common in mammals or why mammals with the smallest home ranges tend to be close to $100 \mathrm{~g}$ in mass but why these patterns obtain for rodents. Other mammalian taxa simply do not converge on this size either intraspecifically (Meiri et al. 2004a) or interspecifically (Alroy 1998; this study).

Why do we see the pattern observed by Marquet and Taper (1998)? At the continental scale, we believe no real pattern is apparent. The fact that North America and Europe have no elephants surely does not mean that they cannot exist there-in fact, a large proboscidean clade inhabited both continents as late as the end of the last ice age. Furthermore, elephants inhabit Sri Lanka $(65,000$ $\mathrm{km}^{2}$ ) today, so their absence from larger landmasses does not mean areal size is a restrictive factor. Likewise, Roth (1992) argued that Sicily $\left(25,460 \mathrm{~km}^{2}\right)$ could have harbored a population of 3,000 15-ton elephants. As for the smallest end of the spectrum, Y. Mandelik (unpublished data) calculated the density of one of the world's smallest mammals, the 2.5-g (Nowak 1999) Suncus etruscus as 16 individuals per hectare in the Judean foothills. As Marquet and Taper (1998) themselves pointed out, for the smallest mammals, continental size is not restrictive. It even seems that, given suitable habitat, mammals weighing much less than $100 \mathrm{~g}$ can probably maintain viable populations on very small islands indeed. Another important matter in this regard is actual density. Marquet and Taper (1998) derived their equations from the area required per average individual within a species of a particular size. However, their equations are correct only for strictly territorial species, with zero overlap between neighboring territories. As Case (1978) pointed out, the question of territoriality is important in accounting for body size patterns in insular mammals.

Density compensation and overcompensation (MacArthur et al. 1972; Dunham et al. 1978; Gliwicz 1980; Brown and Lomolino 1998) can also "allow" more animals to inhabit a given area than theory (Marquet and Taper 1998) might imply (Blackburn and Gaston 1996). If territoriality and density compensation are not independent of mass it might not be $100-\mathrm{g}$ mammals that have the 
highest population densities on islands. Finally, there simply are not enough paleontological data to support the notion that populations of animals in the "wrong" size range go extinct on islands (Roth 1992).

We think that the main question to be answered is, Can all mammalian species be assumed to have a single optimal mass (Blackburn and Gaston 1996)? We believe that, both on empirical and conceptual grounds, defining one optimal size for a diverse assemblage such as the class Mammalia is unwarranted. Optimal size can and does vary even within single species in response to many factors such as climate (Meiri and Dayan 2003), resource availability, and community composition (Dayan and Simberloff 1998). It can vary between the sexes (generating sexual size dimorphism) and with time (Yom-Tov 2003). We do not think a 100-g rodent is in any way more "optimal" or fit than a 3-g shrew, a 200,000-g deer, or a 5,500-g fox. These animals are all adapted to their particular life-history characteristics, environments, and feeding habits (Blackburn and Gaston 1996). Evolution is not about an optimization to an unchanging single mode but about grasping temporally changing and always context-dependent opportunities.

\section{Acknowledgments}

We thank R. Asher, H. Baagøe, D. Balkwill, S. Bruaux, Y. Chang Man, G. Coulon, J. Cuisin, J. Chupasko, J. Dawson, H. Endo, J. Eger, P. Giere, M. Gosselin, R. Harbord, D. Hills, T. Holmes, G. Jarrell, L. M. Kenness, R. Kraft, Y. Kunimatsu, E. A. Lacey, G. Lenglet, H. K. Lua, T. J. McCarthy, S. B. McLaren, D. Nagorsen, B. Randall, F. Renoult, A. G. Rol, A. Ross, T. Shariv, B. Shepherd, C. Smeenk, W. Stanley, C. Stefen, R. Symonds, G. Véron, and S. M. Woodward, for their invaluable help during data collecting. We thank J. Calder and E. Meijaard for data on island areas. Y. Mandelik kindly let us use data from her extensive survey of the Judean Hills fauna. We thank D. A. Kelt for supplying mammalian home range data. We are especially indebted to O. Barnea for help with the bootstrap analysis. T.D. wishes to thank colleagues at the National Center for Ecological Analysis and Synthesis body size working group for helpful discussion and support. We thank L. Heaney for valuable discussion. V. L. Roth and two anonymous referees provided insightful comments on an earlier version of this manuscript. This study was supported by U.S.Israel Binational Scientific Foundation grant 9800477.

\section{Literature Cited}

Abe, H., ed. 1994. A pictorial guide to the mammals of Japan. Japan Wildlife Research Center, Tokyo.

Alcover, J. A., and M. McMinn. 1994. Predators of vertebrates on islands. BioScience 44:12-18.
Alderton, D. 1994. Foxes, wolves and wild dogs of the world. Facts on File, New York.

Alroy, J. 1998. Cope's rule and the dynamics of body mass evolution in North American fossil mammals. Science 280:731-734.

- 2003. Taxonomic inflation and body mass distributions in North American fossil mammals. Journal of Mammalogy 84:431433.

Blackburn, T. M., and K. J. Gaston. 1994. Animal body size distributions: patterns, mechanisms and implications. Trends in Ecology \& Evolution 4:471-474.

- 1996. On being the right size: different definitions of "right." Oikos 75:551-557.

- 1998. The distribution of mammal body masses. Diversity and Distributions 4:121-133.

Boback, S. M., and C. Guyer. 2003. Empirical evidence for an optimal body size in snakes. Evolution 57:345-351.

Bokma, F. 2001. Evolution of body size: limitations of an energetic definition of fitness. Functional Ecology 16:696-699.

Bourliere, F. 1975. Mammals small and large: the ecological implications of size. Pages 1-8 in F. B. Golley, K. Petrusewicz, and L. Ryszkowski, eds. Small mammals: their productivity and population dynamics. Cambridge University Press, Cambridge.

Brown, J. H. 1995. Macroecology. University of Chicago Press, Chicago.

Brown, J. H., and M. V. Lomolino. 1998. Biogeography. Sinauer, Sunderland, MA.

Brown, J. H., and B. A. Maurer. 1989. Macroecology: the division of food and space among species on continents. Science 243:11451150 .

Brown, J. H., P. A. Marquet, and M. L. Taper. 1993. Evolution of body size: consequences of an energetic definition of fitness. American Naturalist 142:573-584.

Brown, J. H., M. L. Taper, and P. A. Marquet. 1996. Darwinian fitness and reproductive power: reply to Kozlowski. American Naturalist 147:1092-1097.

Burness, G. P., J. Diamond, and T. Flannery. 2001. Dinosaurs, dragons, and dwarfs: the evolution of maximal body size. Proceedings of the National Academy of Sciences of the USA 98:14518-14523.

Case, T. J. 1978. A general explanation for insular body size trends in terrestrial vertebrates. Ecology 59:1-18.

Chown, S. L., and K. J. Gaston. 1997. The species-body size distribution: energy, fitness and optimality. Functional Ecology 11:365375.

Clarke, A. 2003. Costs and consequences of evolutionary temperature adaptation. Trends in Ecology \& Evolution 18:573-581.

Creel, S., and D. Macdonald. 1995. Sociality, group size, and reproductive suppression among carnivores. Advances in the Study of Behaviour 24:203-257.

Damuth, J. 1993. Cope's rule, the island rule, and the scaling of mammalian population density. Nature 365:748-750.

Dayan, T., and D. Simberloff. 1998. Size patterns among competitors: ecological character displacement and character release in mammals, with special reference to island populations. Mammal Review 28:99-124.

De La Rosa, C. L., and C. C. Nocke. 2000. A guide to the carnivores of Central America. University of Texas Press, Austin.

Dunham, A. E., D. W. Tinkle, and J. W. Gibbons. 1978. Body size in island lizards: a cautionary tale. Ecology 59:1230-1238.

Eder, T., and D. Pattie. 2001. Mammals of British Columbia. Lone Pine, Vancouver. 
Egi, N. 2001. Body mass estimates in extinct mammals from limb bone dimensions: the case of North American hyaenodontids. Paleontology 44:497-528.

Etienne, R. S., and H. Olff. 2004. How dispersal limitation shapes the species-body size distributions in local communities. American Naturalist 163:69-83.

Foster, B. J. 1964. Evolution of mammals on islands. Nature 202: 234-235.

Gardezi, T., and J. da Silva. 1999. Diversity in relation to body size in mammals: a comparative study. American Naturalist 153:110 123.

Ginsberg, J. R. 2000. Biodiversity of mammals. Pages 777-810 in S. A. Levin, ed. Encyclopedia of biodiversity. Vol. 3. Academic Press, San Diego, CA.

Gittleman, J. L. 1985. Carnivore body size: ecological and taxonomic correlates. Oecologia (Berlin) 67:540-554.

Gittleman, J. L., and B. Van Valkenburgh. 1997. Sexual dimorphism in the canines and skulls of carnivores: effects of size, phylogeny and behavioural ecology. Journal of Zoology (London) 242:97117.

Gliwicz, J. 1980. Island populations of rodents: their organization and functioning. Biological Reviews 55:109-138.

Gould, S. J. 1988. Trends as change in variance: a new slant on progress and directionality in evolution. Journal of Paleontology 62:319-329.

Heaney, L. R. 1978. Island area and body size of insular mammals: evidence from the tri-colored squirrel (Callosciurus prevosti) of Southeast Asia. Evolution 32:29-44.

- 1984. Mammalian species richness on islands on the Sunda Shelf, Southeast Asia. Oecologia (Berlin) 61:11-17.

- 1986. Biogeography of mammals in SE Asia: estimates of rates of colonization, extinction and speciation. Biological Journal of the Linnean Society 28:127-165.

Helgen, K. M., and D. E. Wilson. 2003. Taxonomic status and conservation relevance of the raccoons (Procyon spp.) of the West Indies. Journal of Zoology (London) 259:69-76.

Helin, S., N. Ohtaishi, and L. Houji. 1999. The mammalian of China. China Forestry, Beijing.

Hutchinson, G. E., and R. H. MacArthur. 1959. A theoretical ecological model of size distributions among species of animals. American Naturalist 93:117-125.

Ikeda, H., Y. Ono, M. Baba, T. Doi, and T. Iwamoto. 1982. Ranging and activity patterns of three nocturnal viverrids in Omo National Park, Ethiopia. African Journal of Ecology 20:179-186.

Johnson, D. D. P., D. W. Macdonald, and A. J. Dickman. 2000. An analysis and review of the sociobiology of the Mustelidae. Mammal Review 30:171-196.

Johnson, W. E., T. K. Fuller, and W. L. Franklin. 1996. Sympatry in canids: a review and assessment. Pages 189-218 in J. L. Gittleman, ed. Carnivore behavior, ecology, and evolution. Vol. 2. Cornell University Press, Ithaca, NY.

Jones, K. E., and A. Purvis. 1997. An optimum body size for mammals? comparative evidence from bats. Functional Ecology 11:751756.

Kanchanasakha, B., S. Simcharoen, and U. Tin-Than. 1998. Carnivores of mainland South East Asia. World Wildlife Fund, Bangkok.

Kays, R. W. 2000. The behavior and ecology of olingos (Bassaricyon gabbii) and their competition with kinkajous (Potos flavus) in central Panama. Mammalia 64:1-10.

Kelt, D. E., and D. Van Vuren. 1999. Energetic constraints and the relationship between body size and home range area in mammals. Ecology 80:337-340.

- 2001. The ecology and macroecology of mammalian home range area. American Naturalist 157:637-645.

King, C. M. 1989. The advantages and disadvantages of small size to weasels, Mustela species. Pages 302-334 in J. L. Gittleman, ed. Carnivore behavior, ecology, and evolution. Vol. 1. Chapman \& Hall, London.

Kingdon, J. 1997. The Kingdon field guide to African mammals. Academic Press, San Diego, CA.

Kitchener, A. 1991. The natural history of the wild cats. Comstock, New York.

Kozlowski, J. 1996. Energetic definition of fitness? yes, but not that one. American Naturalist 147:1087-1091.

2002. Theoretical and empirical status of Brown, Marquet and Taper's model of species-size distribution. Functional Ecology 16:540-542.

Kruuk, H. 2002. Hunter and hunted: relationships between carnivores and people. Cambridge University Press, Cambridge.

Lariviere, S. 1999a. Lontra longicaudis. Mammalian Species 609:1-5. 1999b. Lontra provocax. Mammalian Species 610:1-4.

Lawlor, T. E. 1982. The evolution of body size in mammals: evidence from insular populations in Mexico. American Naturalist 119:5472.

Lomolino, M. V. 1985. Body size of mammals on islands: the island rule reexamined. American Naturalist 125:310-316.

Lovegrove, B. G., and L. Haines. 2004. The evolution of placental mammal body sizes: evolutionary history, form, and function. Oecologia (Berlin) 138:13-27.

MacArthur, R. H., J. M. Diamond, and J. R. Karr. 1972. Density compensation in island faunas. Ecology 53:330-342.

Macdonald, D. W., ed. 1984. The encyclopedia of mammals. Allen \& Unwin, London.

1992. The velvet claw: a natural history of the carnivores. BBC Books, London.

Maiorana, V. C. 1990. Evolutionary strategies and body size in a guild of mammals. Pages 69-102 in J. Damuth and B. J. MacFadden, eds. Body size in mammalian paleobiology. Cambridge University Press, Cambridge.

Marquet, P. A., and M. L. Taper. 1998. On size and area: patterns of mammalian body size extremes across landmasses. Evolutionary Ecology 12:127-139.

Marquet, P. A., S. A. Navarrete, and J. C. Castilla. 1995. Body size, population density, and the energetic equivalence rule. Journal of Animal Ecology 64:325-332.

Maurer, B. A., J. H. Brown, and R. D. Rusler. 1992. The micro and the macro in body size evolution. Evolution 46:939-953.

McNab, B. K. 1963. Bioenergetics and the determination of home range size. American Naturalist 97:133-140.

. 2000. Energy constraints on carnivore diet. Nature 407:584.

Medellin, R. A., G. Caballos, and H. Zarza. 1998. Spilogale pygmaea. Mammalian Species 600:1-3.

Meijaard, E. 2003. Mammals of south-east Asian islands and their Late Pleistocene environments. Journal of Biogeography 30:12451257.

Meiri, S., and T. Dayan. 2003. On the validity of Bergmann's rule. Journal of Biogeography 30:331-351.

Meiri, S., T. Dayan, and D. Simberloff. 2004a. Body size of insular carnivores: little support for the island rule. American Naturalist 163:469-479. 
2004b. Carnivores, biases and Bergmann's rule. Biological Journal of the Linnean Society 81:579-588.

Moehlman, P. D., and H. Hofer. 1997. Cooperative breeding, reproductive suppression, and body mass in canids. Pages 76-128 in N. G. Solomon and J. A. French, eds. Cooperative breeding in mammals. Cambridge University Press, Cambridge.

Moore, C. M., and P. W. Collins. 1995. Urocyon littoralis. Mammalian Species 489:1-7.

Nellis, D. W., and C. O. R. Everard. 1983. The biology of the mongoose in the Caribbean. Studies on the Fauna of Curacao and Other Caribbean Islands 64:1-162.

Nowak, R. M. 1999. Walker's mammals of the world. 6th ed. Johns Hopkins University Press, Baltimore.

Perrin, N. 1998. On body size, energy and fitness. Functional Ecology 12:500-502.

Purvis, A., C. D. L. Orme, and K. Dolphin. 2003. Why are most species small-bodied? a phylogenetic view. Pages 155-173 in T. M. Blackburn and K. J. Gaston, eds. Macroecology: concepts and consequences. Blackwell Science, Oxford.

Raia, P., C. Barbera, and M. Conte. 2003. The fast life of a dwarfed giant. Evolutionary Ecology 17:293-312.

Redford, K. H., and J. F. Eisenberg. 1992. Mammals of the Neotropics. University of Chicago Press, Chicago.

Reid, F. A. 1997. A field guide to the mammals of Central America and southeast Mexico. Oxford University Press, Oxford.

Roth, V. L. 1992. Inferences from allometry and fossils: dwarfing of elephants on islands. Pages 259-288 in D. Futuyma and J. Antonovics, eds. Oxford surveys in evolutionary biology. Vol. 8. Oxford University Press, Oxford.

Roy, K., D. Jablonski, and K. K. Martien. 2000. Invariant sizefrequency distributions along a latitudinal gradient in marine bivalves. Proceedings of the National Academy of Sciences of the USA 97:13150-13155.

Scott, S. N., S. C. Clegg, S. P. Blomberg, J. Kikkawa, and I. P. F. Owens. 2003. Morphological shifts in island-dwelling passerines: the roles of generalist foraging and niche expansion. Evolution 57: 2147-2156.

Silva, M. 1998. Allometric scaling of body length: elastic or geometric similarity in mammalian design. Journal of Mammalogy 79:2032.

Silva, M., and J. A. Downing. 1995. CRC handbook of mammalian body masses. CRC, New York.

Smith, F. A., S. K. Lyons, S. K. Morgan Ernest, K. E. Jones, D. M. Kaufman, T. Dayan, P. A. Marquet, J. H. Brown, and J. P. Haskell. 2003. Body mass of late Quaternary mammals. Ecology 84:3403.

Smith, F. A., J. H. Brown, J. P. Haskell, S. K. Lyons, J. Alroy, E. L. Charnov, T. Dayan, et al. 2004. Similarity of mammalian body size across the taxonomic hierarchy and across space and time. American Naturalist. 163:672-691.

Smith, R. J. 1994. Degrees of freedom in interspecific allometry: an adjustment for the effects of phylogenetic constraint. American Journal of Physical Anthropology 93:95-107.

Smith, R. J., and W. L. Jungers. 1997. Body mass in comparative primatology. Journal of Human Evolution 32:523-559.

Stanley, S. M. 1973. An explanation for Cope's rule. Evolution 27: $1-26$.

Sunquist, M., and F. Sunquist. 2002. Wild cats of the world. University of Chicago Press, Chicago.

Symonds, M. R. E. 1999. Insectivore life histories: further evidence against an optimum body size for mammals. Functional Ecology 13:508-513.

Taylor, M. E., and J. Matheson. 1999. A craniometric comparison of African and Asian mongooses in the genus Herpestes (Carnivora, Herpestidae). Mammalia 63:449-464.

Van Valen, L. M. 1973. Pattern and the balance of nature. Evolutionary Theory 1:31-49.

Van Valkenburgh, B. 1990. Skeletal and dental predictors of body mass in carnivores. Pages 181-205 in J. Damuth and B. J. MacFadden, eds. Body size in mammalian paleobiology. Cambridge University Press, Cambridge.

Verts, B. J., L. N. Carraway, and A. Kinlaw. 2001. Spilogale gracilis. Mammalian Species 674:1-10.

Von den Driesch, A. 1976. A guide to the measurement of animal bones from archaeological sites. Peabody Museum Bulletin, Cambridge.

Wassersug, R. J., H. Yang, J. J. Sepkosky Jr., and D. M. Raup. 1979. The evolution of body size on islands: a computer simulation. American Naturalist 114:287-295.

Weckerly, F. W. 1998. Sexual-size dimorphism: influence of mass and mating systems in the most dimorphic mammals. Journal of Mammalogy 79:33-52.

Wilkinson, D. M., and H. J. O'Regan. 2003. Modeling differential extinctions to understand big cat distribution on Indonesian islands. Global Ecology and Biogeography 12:519-524.

Yalden, D. 1999. The history of British mammals. Poyser, London. Yom-Tov, Y. 2003. Body sizes of carnivores commensal with humans have increased over the past 50 years. Functional Ecology 17:323327.

Zeveloff, S. I. 2003. A review of the taxonomic and conservation statuses of the island raccoons. Small Carnivore Conservation 29: $10-12$.

Editor: Jonathan B. Losos Associate Editor: Steven L. Chown 


\title{
Appendix from S. Meiri et al., "Insular Carnivore Biogeography: Island Area and Mammalian Optimal Body Size"
}

\author{
(Am. Nat., vol. 165, no. 4, p. 505)
}

\section{Carnivore Species Data}

Table A1

Carnivore biogeography and body masses

\begin{tabular}{|c|c|c|c|}
\hline Species & Log mass $(\mathrm{g})$ & Source & Occurs on \\
\hline Acinonyx jubatus & 4.70 & Kingdon 1997 & Continents only \\
\hline Ailuropoda melanoleuca & 5.07 & Nowak 1999 & Continents only \\
\hline Ailurus fulgens & 3.69 & Silva and Downing 1995 & Continents only \\
\hline Alopex lagopus & 3.48 & This study & Continents and islands \\
\hline Aonyx capensis & 4.10 & Silva and Downing 1995 & Continents only \\
\hline Aonyx cinerea & 3.48 & Nowak 1999 & Continents and islands \\
\hline Aonyx congica & 4.30 & Kingdon 1997 & Continents and islands \\
\hline Arctictis binturong & 4.16 & Kanchanasakha et al. 1998 & Continents and islands \\
\hline Arctogalidia trivirgata & 3.35 & Kanchanasakha et al. 1998 & Continents and islands \\
\hline Arctonyx collaris & 4.02 & Kanchanasakha et al. 1998 & Continents and islands \\
\hline Atelocynus microtis & 3.98 & Nowak 1999 & Continents only \\
\hline Atilax paludinosus & 3.56 & Kingdon 1997 & Continents and islands \\
\hline Bassaricyon alleni & 3.09 & Smith et al. 2003 & Continents only \\
\hline Bassaricyon beddardi & 3.09 & Nowak 1999 & Continents only \\
\hline Bassaricyon gabbii & 2.90 & Kays 2000 & Continents only \\
\hline Bassaricyon lasius & 3.09 & Nowak 1999 & Continents only \\
\hline Bassaricyon pauli & 3.09 & Nowak 1999 & Continents only \\
\hline Bassariscus astutus & 3.00 & Egi 2001 & Continents and islands \\
\hline Bassariscus sumichrasti & 3.04 & Reid 1997 & Continents only \\
\hline Bdeogale crassicauda & 3.23 & Kingdon 1997 & Continents and islands \\
\hline Bdeogale jacksoni & 3.40 & Kingdon 1997 & Continents only \\
\hline Bdeogale nigripes & 3.44 & Kingdon 1997 & Continents only \\
\hline Canis adustus & 3.98 & Kingdon 1997 & Continents only \\
\hline Canis aureus & 3.96 & This study & Continents and islands \\
\hline Canis latrans & 4.03 & This study & Continents and islands \\
\hline Canis lupus & 4.54 & This study & Continents and islands \\
\hline Canis mesomelas & 3.93 & Kingdon 1997 & Continents only \\
\hline Canis rufus & 4.45 & Alderton 1994 & Continents and islands \\
\hline Canis simensis & 4.14 & Kingdon 1997 & Continents only \\
\hline Cerdocyon thous & 3.79 & Redford and Eisenberg 1992 & Continents and islands \\
\hline Chrotogale owstoni & 3.40 & Kanchanasakha et al. 1998 & Continents only \\
\hline Chrysocyon brachiurus & 4.37 & Silva and Downing 1995 & Continents only \\
\hline Civettictis civetta & 4.13 & Kingdon 1997 & Continents and islands \\
\hline Conepatus chinga & 3.30 & Silva and Downing 1995 & Continents only \\
\hline Conepatus humboldti & 3.01 & Weckerly 1998 & Continents and islands \\
\hline Conepatus leuconotus & 3.01 & Weckerly 1998 & Continents only \\
\hline Conepatus mesolecus & 3.36 & Van Valkenburgh 1990 & Continents only \\
\hline Conepatus semistriatus & 3.39 & Reid 1997 & Continents and islands \\
\hline Crocuta crocuta & 4.81 & Kingdon 1997 & Continents only \\
\hline Crossarchus alexandri & 3.18 & Kingdon 1997 & Continents only \\
\hline Crossarchus ansorgei & 3.00 & Macdonald 1984 & Continents only \\
\hline Crossarchus obscurus & 3.10 & Kingdon 1997 & Continents only \\
\hline Crossarchus platycephalus & 3.10 & Kingdon 1997 & Continents only \\
\hline Cryptoprocta ferox & 3.98 & Nowak 1999 & Islands only \\
\hline
\end{tabular}


App. from S. Meiri et al., "Insular Carnivores and Optimal Size"

Table A1 (Continued)

\begin{tabular}{|c|c|c|c|}
\hline Species & Log mass (g) & Source & Occurs on \\
\hline Cuon alpinus & 4.20 & Nowak 1999 & Continents and islands \\
\hline Cynictis penicillata & 2.79 & Kingdon 1997 & Continents only \\
\hline Cynogale bennettii & 3.60 & Kanchanasakha et al. 1998 & Continents and islands \\
\hline Cynogale lowei & 3.60 & Helin et al. 1999 & Continents only \\
\hline Diplogale hosei & 3.38 & Mass estimate $^{a}$ & Islands only \\
\hline Dologale dybowskii & 2.51 & Kingdon 1997 & Continents only \\
\hline Dusicyon australis & 4.20 & Mass estimate $^{\mathrm{a}}$ & Islands only \\
\hline Eira barbara & 3.62 & Van Valkenburgh 1990 & Continents and islands \\
\hline Eupleres goudotti & 3.48 & Nowak 1999 & Islands only \\
\hline Felis aurata & 4.02 & Nowak 1999 & Continents only \\
\hline Felis badia & 3.54 & Sunquist and Sunquist 2002 & Islands only \\
\hline Felis bengalensis & 3.60 & Kanchanasakha et al. 1998 & Continents and islands \\
\hline Felis bieti & 3.74 & Helin et al. 1999 & Continents only \\
\hline Felis canadensis & 3.94 & This study & Continents and islands \\
\hline Felis caracal & 4.06 & This study & Continents only \\
\hline Felis chaus & 3.85 & Sunquist and Sunquist 2002 & Continents and islands \\
\hline Felis colocolo & 3.43 & Sunquist and Sunquist 2002 & Continents only \\
\hline Felis concolor & 4.62 & This study & Continents and islands \\
\hline Felis geoffroyi & 3.66 & Sunquist and Sunquist 2002 & Continents only \\
\hline Felis guigna & 3.35 & Redford and Eisenberg 1992 & Continents and islands \\
\hline Felis iriomotensis & 3.59 & Abe 1994 & Islands only \\
\hline Felis jacobita & 3.60 & Sunquist and Sunquist 2002 & Continents only \\
\hline Felis lynx & 4.38 & Kitchener 1991 & Continents and islands \\
\hline Felis manul & 3.54 & Sunquist and Sunquist 2002 & Continents only \\
\hline Felis margarita & 3.40 & Sunquist and Sunquist 2002 & Continents only \\
\hline Felis marmorata & 3.44 & Gittleman 1985 & Continents and islands \\
\hline Felis nigripes & 3.20 & Sunquist and Sunquist 2002 & Continents only \\
\hline Felis pardalis & 4.03 & This study & Continents and islands \\
\hline Felis pardina & 4.02 & Sunquist and Sunquist 2002 & Continents only \\
\hline Felis planiceps & 3.27 & Kanchanasakha et al. 1998 & Continents and islands \\
\hline Felis rubiginosa & 3.13 & Sunquist and Sunquist 2002 & Continents and islands \\
\hline Felis rufus & 4.02 & This study & Continents and islands \\
\hline Felis serval & 4.06 & Sunquist and Sunquist 2002 & Continents only \\
\hline Felis silvestris & 3.50 & This study & Continents and islands \\
\hline Felis temmincki & 4.07 & Kanchanasakha et al. 1998 & Continents and islands \\
\hline Felis tigrina & 3.41 & Sunquist and Sunquist 2002 & Continents only \\
\hline Felis viverrina & 3.91 & Sunquist and Sunquist 2002 & Continents and islands \\
\hline Felis wiedii & 3.51 & Sunquist and Sunquist 2002 & Continents and islands \\
\hline Felis yaguaroundi & 3.75 & Sunquist and Sunquist 2002 & Continents only \\
\hline Fennecus zerda & 3.00 & Nowak 1999 & Continents only \\
\hline Fossa fossana & 3.25 & Creel and Macdonald 1995 & Islands only \\
\hline Galerella nigrita & 2.78 & Taylor and Matheson 1999 & Continents only \\
\hline Galerella ochracea & 2.78 & Taylor and Matheson 1999 & Continents only \\
\hline Galerella pulverulenta & 2.94 & Silva and Downing 1995 & Continents only \\
\hline Galerella sanguinea & 2.81 & Silva and Downing 1995 & Continents and islands \\
\hline Galictis cuja & 3.00 & Nowak 1999 & Continents and islands \\
\hline Galictis vittata & 3.37 & Silva and Downing 1995 & Continents only \\
\hline Galidia elegance & 2.91 & Creel and Macdonald 1995 & Islands only \\
\hline Galidictis fasciata & 2.74 & Smith et al. 2003 & Islands only \\
\hline Galidictis grandidieri & 3.15 & Smith et al. 2003 & Islands only \\
\hline Genetta abyssinica & 3.22 & Kingdon 1997 & Continents only \\
\hline Genetta angolensis & 3.22 & Kingdon 1997 & Continents only \\
\hline Genetta genetta & 3.25 & Kingdon 1997 & Continents and islands \\
\hline Genetta johnstoni & 3.30 & Kingdon 1997 & Continents only \\
\hline Genetta maculata & 3.35 & Smith et al. 2003 & Continents and islands \\
\hline Genetta pardina & 3.36 & Mass estimate ${ }^{\mathrm{b}}$ & Continents only \\
\hline Genetta servalina & 3.18 & Kingdon 1997 & Continents and islands \\
\hline Genetta thierryi & 3.15 & Kingdon 1997 & Continents only \\
\hline Genetta tigrina & 3.33 & Kingdon 1997 & Continents only \\
\hline Genetta victoriae & 3.48 & Kingdon 1997 & Continents only \\
\hline Gulo gulo & 3.96 & This study & Continents and islands \\
\hline
\end{tabular}


App. from S. Meiri et al., "Insular Carnivores and Optimal Size"

Table A1 (Continued)

\begin{tabular}{|c|c|c|c|}
\hline Species & Log mass $(\mathrm{g})$ & Source & Occurs on \\
\hline Helogale hirtula & 2.44 & Kingdon 1997 & Continents only \\
\hline Helogale parvula & 2.45 & Kingdon 1997 & Continents only \\
\hline Hemigalus derbyanus & 3.30 & Kanchanasakha et al. 1998 & Continents and islands \\
\hline Herpestes brachyurus & 3.40 & Kanchanasakha et al. 1998 & Continents and islands \\
\hline Herpestes edwardsi & 3.13 & Egi 2001 & Continents and islands \\
\hline Herpestes fuscus & 3.13 & Silva and Downing 1995 & Continents and islands \\
\hline Herpestes ichneumon & 3.36 & This study & Continents only ${ }^{e}$ \\
\hline Herpestes javanicus & 2.86 & This study & Continents and islands \\
\hline Herpestes naso & 3.56 & Kingdon 1997 & Continents only \\
\hline Herpestes semitorquatus & 3.50 & Mass estimate ${ }^{c}$ & Islands only \\
\hline Herpestes smithii & 3.23 & Gittleman 1985 & Continents and islands \\
\hline Herpestes urva & 3.38 & Gittleman 1985 & Continents and islands \\
\hline Herpestes vitticollis & 3.46 & Silva and Downing 1995 & Continents and islands \\
\hline Hyaena hyaena & 4.52 & This study & Continents only \\
\hline Ichneumia albicauda & 3.56 & Kingdon 1997 & Continents and islands \\
\hline Ictonyx striatus & 3.02 & Kingdon 1997 & Continents only \\
\hline Liberiictis kuhni & 3.33 & Kingdon 1997 & Continents only \\
\hline Lontra canadensis & 3.92 & This study & Continents and islands \\
\hline Lontra felina & 3.60 & Johnson et al. 2000 & Continents and islands \\
\hline Lontra longicaudis & 4.00 & Lariviere $1999 a$ & Continents and islands \\
\hline Lontra provocax & 3.88 & Lariviere $1999 b$ & Continents and islands \\
\hline Lutra lutra & 3.92 & This study & Continents and islands \\
\hline Lutra maculicollis & 3.72 & Kingdon 1997 & Continents only \\
\hline Lutra sumatrana & 3.74 & Kanchanasakha et al. 1998 & Continents and islands \\
\hline Lutrogale perspicillata & 3.95 & Kanchanasakha et al. 1998 & Continents and islands \\
\hline Lycalopex vetulus & 3.53 & Nowak 1999 & Continents only \\
\hline Lycaon pictus & 4.43 & Kingdon 1997 & Continents only \\
\hline Lyncodon patagonicus & 2.35 & Silva and Downing 1995 & Continents only \\
\hline Macrogalidia musschenbroekii & 3.71 & Burness et al. 2001 & Islands only \\
\hline Martes americana & 3.00 & This study & Continents and islands \\
\hline Martes flavigula & 3.40 & Kanchanasakha et al. 1998 & Continents and islands \\
\hline Martes foina & 3.10 & This study & Continents and islands \\
\hline Martes gwatkinsi & 3.31 & Smith et al. 2003 & Continents only \\
\hline Martes martes & 3.11 & Nowak 1999 & Continents and islands \\
\hline Martes melampus & 3.02 & This study & Continents and islands \\
\hline Martes pennanti & 3.53 & This study & Continents and islands \\
\hline Martes zibellina & 3.08 & Johnson et al. 2000 & Continents and islands \\
\hline Meles meles & 3.98 & This study & Continents and islands \\
\hline Mellivora capensis & 3.91 & This study & Continents only \\
\hline Melogale everetti & 3.30 & Johnson et al. 2000 & Islands only \\
\hline Melogale moschata & 2.91 & This study & Continents and islands \\
\hline Melogale orientalis & 2.93 & This study & Islands only \\
\hline Melogale personata & 3.30 & Kanchanasakha et al. 1998 & Continents only \\
\hline Mephitis macroura & 3.23 & Silva and Downing 1995 & Continents only \\
\hline Mephitis mephitis & 3.38 & Johnson et al. 2000 & Continents and islands \\
\hline Mungos gambianus & 3.18 & Kingdon 1997 & Continents only \\
\hline Mungos mungo & 3.27 & Kingdon 1997 & Continents only ${ }^{\mathrm{e}}$ \\
\hline Mungotictis decemlineata & 2.81 & Nowak 1999 & Islands only \\
\hline Mustela africana & 2.73 & Smith et al. 2003 & Continents only \\
\hline Mustela altaica & 2.34 & Nowak 1999 & Continents only \\
\hline Mustela erminea & 2.35 & This study ${ }^{\mathrm{d}}$ & Continents and islands \\
\hline Mustela eversmanni & 3.23 & Johnson et al. 2000 & Continents only \\
\hline Mustela felipei & 2.14 & Smith et al. 2003 & Continents only \\
\hline Mustela frenata & 2.38 & Eder and Pattie 2001 & Continents and islands \\
\hline Mustela kathiah & 2.30 & Helin et al. 1999 & Continents and islands \\
\hline Mustela lutreola & 2.77 & Gittleman 1985 & Continents only ${ }^{\mathrm{e}}$ \\
\hline Mustela lutreolina & 2.79 & Nowak 1999 & Islands only \\
\hline Mustela macrodon & 3.39 & Mass estimate ${ }^{\mathrm{b}}$ & Continents and islands \\
\hline Mustela nigripes & 2.93 & Silva and Downing 1995 & Continents only \\
\hline Mustela nivalis & 1.91 & This study $^{\mathrm{d}}$ & Continents and islands \\
\hline Mustela nudipes & 3.11 & Kanchanasakha et al. 1998 & Continents and islands \\
\hline
\end{tabular}


App. from S. Meiri et al., "Insular Carnivores and Optimal Size"

Table A1 (Continued)

\begin{tabular}{|c|c|c|c|}
\hline Species & Log mass $(\mathrm{g})$ & Source & Occurs on \\
\hline Mustela putorius & 3.01 & Johnson et al. 2000 & Continents and islands \\
\hline Mustela sibirica & 2.72 & This study & Continents and islands \\
\hline Mustela strididorsa & 3.18 & Kanchanasakha et al. 1998 & Continents only \\
\hline Mustela vison & 3.00 & This study & Continents and islands \\
\hline Mydaus javanensis & 3.40 & Nowak 1999 & Islands only \\
\hline Mydaus marchei & 3.40 & Nowak 1999 & Islands only \\
\hline Nandinia binotata & 3.41 & Kingdon 1997 & Continents and islands \\
\hline Nasua narica & 3.58 & Silva and Downing 1995 & Continents and islands \\
\hline Nasua nasua & 3.52 & Silva and Downing 1995 & Continents only ${ }^{e}$ \\
\hline Nasuella olivacea & 3.13 & Smith et al. 2003 & Continents only \\
\hline Neofelis nebulosa & 4.22 & Sunquist and Sunquist 2002 & Continents and islands \\
\hline Nyctereutes procyonoides & 3.69 & This study & Continents and islands \\
\hline Osbornictis piscivora & 3.17 & Nowak 1999 & Continents only \\
\hline Otocyon megalotis & 3.62 & Nowak 1999 & Continents only \\
\hline Paguma larvata & 3.44 & This study & Continents and islands \\
\hline Panthera leo & 5.21 & Silva and Downing 1995 & Continents only \\
\hline Panthera onca & 4.98 & Sunquist and Sunquist 2002 & Continents only \\
\hline Panthera pardus & 4.54 & Kanchanasakha et al. 1998 & Continents and islands \\
\hline Panthera tigris & 5.03 & Nowak 1999 & Continents and islands \\
\hline Panthera uncia & 4.64 & Sunquist and Sunquist 2002 & Continents only \\
\hline Paracynictis selousi & 3.24 & Silva and Downing 1995 & Continents only \\
\hline Paradoxurus hermaphroditus & 3.54 & Kanchanasakha et al. 1998 & Continents and islands \\
\hline Paradoxurus jerdoni & 3.55 & Silva and Downing 1995 & Continents only \\
\hline Paradoxurus lignicolor & 3.54 & Kanchanasakha et al. 1998 & Islands only \\
\hline Paradoxurus zeylonensis & 3.45 & Gittleman 1985 & Islands only \\
\hline Parahyaena brunnea & 4.58 & Silva and Downing 1995 & Continents only \\
\hline Poecilictis libyca & 2.80 & Kingdon 1997 & Continents only \\
\hline Poecilogale albinucha & 2.46 & Kingdon 1997 & Continents only \\
\hline Poiana richardsonii & 2.78 & Kingdon 1997 & Continents and islands \\
\hline Potos flavus & 3.48 & Egi 2001 & Continents and islands \\
\hline Prionodon linsang & 2.85 & Kanchanasakha et al. 1998 & Continents and islands \\
\hline Prionodon pardicolor & 2.85 & Kanchanasakha et al. 1998 & Continents only \\
\hline Procyon cancrivorus & 3.70 & De La Rosa and Nocke 2000 & Continents and islands \\
\hline Procyon gloveralleni & 3.73 & Mass estimate ${ }^{c}$ & Islands only \\
\hline Procyon insularis & 3.82 & Mass estimate ${ }^{c}$ & Islands only \\
\hline Procyon lotor & 3.95 & Eder and Pattie 2001 & Continents and islands \\
\hline Procyon maynardi & 3.69 & Mass estimate ${ }^{c}$ & Islands only \\
\hline Procyon minor & 3.56 & Mass estimate $^{\mathrm{d}}$ & Islands only \\
\hline Procyon pygmaeus & 3.54 & Zeveloff 2003 & Islands only \\
\hline Proteles cristatus & 4.00 & Kingdon 1997 & Continents only \\
\hline Pseudalopex culpaeus & 4.00 & Johnson et al. 1996 & Continents and islands \\
\hline Pseudalopex griseus & 3.54 & Johnson et al. 1996 & Continents and islands \\
\hline Pseudalopex gymnocercus & 3.64 & Moehlman and Hofer 1997 & Continents only \\
\hline Pseudalopex sechurae & 3.48 & Alderton 1994 & Continents only \\
\hline Pteronura brasiliensis & 4.43 & Silva and Downing 1995 & Continents only \\
\hline Rhynchogale melleri & 3.38 & Kingdon 1997 & Continents only \\
\hline Salanoia concolor & 2.90 & Macdonald 1984 & Islands only \\
\hline Speothos venaticus & 3.78 & Reid 1997 & Continents only \\
\hline Spilogale gracilis & 2.68 & Verts et al. 2001 & Continents and islands \\
\hline Spilogale putorius & 2.88 & Egi 2001 & Continents and islands \\
\hline Spilogale pygmaea & 2.37 & Medellin et al. 1998 & Continents only \\
\hline Suricata suricata & 2.90 & Kingdon 1997 & Continents only \\
\hline Taxidea taxus & 3.90 & Nowak 1999 & Continents and islands \\
\hline Tremarctos ornatus & 5.13 & Van Valkenburgh 1990 & Continents only \\
\hline Urocoyon cinereoargenteus & 3.57 & This study & Continents and islands \\
\hline Urocoyon littoralis & 3.28 & Moore and Collins 1995 & Islands only \\
\hline Ursus americanus & 5.19 & Eder and Pattie 2001 & Continents and islands \\
\hline Ursus arctos & 5.51 & Eder and Pattie 2001 & Continents and islands \\
\hline Ursus malayanus & 4.66 & Kanchanasakha et al. 1998 & Continents and islands \\
\hline Ursus thibetanus & 4.98 & Abe 1994 & Continents and islands \\
\hline Ursus ursinus & 4.83 & McNab 2000 & Continents and islands \\
\hline
\end{tabular}


App. from S. Meiri et al., "Insular Carnivores and Optimal Size"

Table A1 (Continued)

\begin{tabular}{lcll}
\hline Species & Log mass $(\mathrm{g})$ & \multicolumn{1}{c}{ Source } & Occurs on \\
\hline Viverra megaspila & 3.93 & Kanchanasakha et al. 1998 & Continents and islands \\
Viverra tangalunga & 3.74 & Kanchanasakha et al. 1998 & Continents and islands \\
Viverra zibetha & 3.93 & Kanchanasakha et al. 1998 & Continents and islands \\
Viverricula indica & 3.34 & This study & Continents and islands \\
Vormela peregusna & 2.41 & This study & Continents only \\
Vulpes benegalensis & 3.38 & Moehlman and Hofer 1997 & Continents only \\
Vulpes cana & 3.00 & Nowak 1999 & Continents only \\
Vulpes chama & 3.60 & Nowak 1999 & Continents only \\
Vulpes corsac & 3.40 & Helin et al. 1999 & Continents only \\
Vulpes ferrilata & 3.59 & Moehlman and Hofer 1997 & Continents only \\
Vulpes macrotis & 3.29 & Silva and Downing 1995 & Continents only \\
Vulpes pallida & 3.41 & Nowak 1999 & Continents only \\
Vulpes rueppelli & 3.28 & This study & Continents and islands \\
Vulpes velox & 3.38 & Silva and Downing 1995 & Continents only \\
Vulpes vulpes & 3.74 & This study & Continents and islands \\
\hline
\end{tabular}

Table A2

Largest and smallest carnivores on islands of different areas

\begin{tabular}{|c|c|c|c|c|}
\hline Island & $\begin{array}{l}\text { Carnivore } \\
\text { richness }\end{array}$ & $\begin{array}{l}\text { Area } \\
\left(\mathrm{km}^{2}\right)\end{array}$ & $\begin{array}{l}\text { Smallest } \\
\text { carnivore }\end{array}$ & $\begin{array}{c}\text { Largest } \\
\text { carnivore }\end{array}$ \\
\hline Admiralty & 6 & 4,310 & Mustela erminea & Ursus arctos \\
\hline Afognak & 4 & 1,809 & Mustela erminea & Ursus arctos \\
\hline Akimiski & 8 & 2,326 & Mustela nivalis & Ursus americanus \\
\hline Akutan & 1 & 36 & Vulpes vulpes & Vulpes vulpes \\
\hline Alaid & 2 & 150 & Mustela erminea & Vulpes vulpes \\
\hline Aland & 5 & 1,505 & Mustela nivalis & Meles meles \\
\hline Amakusa & 1 & 610 & Nyctereutes procyonoides & Nyctereutes procyonoides \\
\hline Andros & 2 & 380 & Martes foina & Meles meles \\
\hline Anglesey & 3 & 712 & Mustela nivalis & Meles meles \\
\hline Anguila & 1 & 12 & Mustela vison & Mustela vison \\
\hline Anticosti & 9 & 7,941 & Mustela erminea & Ursus americanus \\
\hline Arran & 3 & 427 & Vulpes vulpes & Meles meles \\
\hline Asinara & 1 & 52 & Mustela nivalis & Mustela nivalis \\
\hline Attu & 1 & 896 & Alopex lagopus & Alopex lagopus \\
\hline Avery & 1 & 8 & Procyon lotor & Procyon lotor \\
\hline Baker & 2 & 135 & Canis lupus & Ursus americanus \\
\hline Balabac & 1 & 306 & Paradoxurus hermaphroditus & Paradoxurus hermaphroditus \\
\hline Balembangan & 1 & 150 & Lutra perspicillata & Lutra perspicillata \\
\hline Bali & 7 & 5,620 & Melogale orientalis & Panthera tigris \\
\hline Banggi & 4 & 441 & Arctogalidia trivirgata & Lutra perspicillata \\
\hline Bangka & 9 & 11,330 & Prionodon linsang & Ursus malayanus \\
\hline Banks (British Columbia) & 2 & 1,024 & Lontra canadensis & Canis lupus \\
\hline Baranof & 4 & 4,163 & Mustela erminea & Ursus arctos \\
\hline Barra & 1 & 90 & Lutra lutra & Lutra lutra \\
\hline Basilan & 1 & 1,282 & Paradoxurus hermaphroditus & Paradoxurus hermaphroditus \\
\hline Bastimentos & 1 & 52 & Procyon lotor & Procyon lotor \\
\hline Batam & 2 & 470 & Arctogalidia trivirgata & Arctictis binturong \\
\hline Bawean & 2 & 200 & Viverricula indica & Paradoxurus hermaphroditus \\
\hline Belitung & 5 & 4,833 & Prionodon linsang & Viverra tangalunga \\
\hline Biliran & 1 & 498 & Paradoxurus hermaphroditus & Paradoxurus hermaphroditus \\
\hline Bintang & 6 & 1,140 & Aonyx cinerea & Panthera tigris \\
\hline Bioko & 4 & 2,072 & Poiana richardsoni & Aonyx congica \\
\hline Bjorno & 1 & 2 & Mustela erminea & Mustela erminea \\
\hline Bohol & 2 & 3,864 & Paradoxurus hermaphroditus & Viverra tangalunga \\
\hline
\end{tabular}


App. from S. Meiri et al., "Insular Carnivores and Optimal Size"

Table A2 (Continued)

\begin{tabular}{|c|c|c|c|c|}
\hline Island & $\begin{array}{l}\text { Carnivore } \\
\text { richness }\end{array}$ & $\begin{array}{l}\text { Area } \\
\left(\mathrm{km}^{2}\right)\end{array}$ & $\begin{array}{l}\text { Smallest } \\
\text { carnivore }\end{array}$ & $\begin{array}{c}\text { Largest } \\
\text { carnivore }\end{array}$ \\
\hline Borneo & 26 & 743,330 & Prionodon linsang & Ursus malayanus \\
\hline Bornholm & 6 & 588 & Mustela nivalis & Meles meles \\
\hline Britain & 11 & 229,883 & Mustela nivalis & Ursus arctos \\
\hline Broughton & 1 & 128 & Mustela vison & Mustela vison \\
\hline Bruit & 2 & 530 & Felis bengalensis & Lutra sumatrana \\
\hline Bulan & 1 & 91 & Arctogalidia trivirgata & Arctogalidia trivirgata \\
\hline Bunguran (Natuna) & 3 & 1,485 & Arctogalidia trivirgata & Viverra tangalunga \\
\hline Busuanga & 5 & 938 & Herpestes brachyurus & Viverra tangalunga \\
\hline Bute & 2 & 119 & Mustela erminea & Vulpes vulpes \\
\hline Cairn & 2 & 37 & Mustela erminea & Lontra canadensis \\
\hline Calvert & 2 & 329 & Mustela vison & Canis lupus \\
\hline Camiguin & 2 & 255 & Paradoxurus hermaphroditus & Viverra tangalunga \\
\hline Cape Breton & 11 & 10,280 & Mustela erminea & Ursus americanus \\
\hline Catanduanes & 2 & 1,513 & Paradoxurus hermaphroditus & Viverra tangalunga \\
\hline Cebu & 1 & 4,421 & Felis bengalensis & Felis bengalensis \\
\hline Celebes & 1 & 189,070 & Macrogalidia musschenbroekii & Macrogalidia musschenbroekii \\
\hline Charlton & 1 & 93 & Mustela erminea & Mustela erminea \\
\hline Cheju-Do & 4 & 1,860 & Mustela sibirica & Meles meles \\
\hline Chichagof & 5 & 5,449 & Mustela erminea & Ursus arctos \\
\hline Chiloe & 5 & 8,394 & Galictis cuja & Lontra provocax \\
\hline Chios & 4 & 831 & Mustela nivalis & Lutra lutra \\
\hline Con Son & 1 & 51 & Paradoxurus hermaphroditus & Paradoxurus hermaphroditus \\
\hline Conanicut & 1 & 24 & Mustela vison & Mustela vison \\
\hline Corfu & 5 & 592 & Mustela nivalis & Canis aureus \\
\hline Coronation & 2 & 91 & Mustela vison & Lontra canadensis \\
\hline Corsica & 4 & 8,681 & Mustela nivalis & Vulpes vulpes \\
\hline Cozumel & 3 & 490 & Procyon pygmaeus & Nasua nelsoni \\
\hline Crete & 3 & 8,336 & Mustela nivalis & Meles meles \\
\hline Culion & 5 & 400 & Aonyx cinerea & Viverra tangalunga \\
\hline Cumberland & 1 & 145 & Ursus americanus & Ursus americanus \\
\hline Cyprus & 1 & 9,250 & Vulpes vulpes & Vulpes vulpes \\
\hline Dall & 5 & 658 & Mustela erminea & Ursus americanus \\
\hline Deer & 9 & 72 & Mustela erminea & Ursus americanus \\
\hline Dinagat & 1 & 670 & Paradoxurus hermaphroditus & Paradoxurus hermaphroditus \\
\hline Domel & 2 & 250 & Arctogalidia trivirgata & Paradoxurus hermaphroditus \\
\hline Douglas & 2 & 203 & Mustela erminea & Ursus americanus \\
\hline Drejo & 1 & 4 & Mustela erminea & Mustela erminea \\
\hline Duke & 1 & 155 & Canis lupus & Canis lupus \\
\hline Dundas & 1 & 160 & Canis lupus & Canis lupus \\
\hline Elba & 1 & 224 & Martes martes & Martes martes \\
\hline Enggano & 1 & 397 & Paradoxurus hermaphroditus & Paradoxurus hermaphroditus \\
\hline Espirito Santo & 1 & 100 & Bassariscus astutus & Bassariscus astutus \\
\hline Esther & 2 & 133 & Mustela vison & Lontra canadensis \\
\hline Etolin & 5 & 889 & Mustela erminea & Ursus americanus \\
\hline Euboea (Evvoia) & 4 & 1,467 & Mustela nivalis & Lutra lutra \\
\hline Falster & 4 & 514 & Mustela nivalis & Vulpes vulpes \\
\hline Fano & 1 & 57 & Mustela erminea & Mustela erminea \\
\hline Farasan Al kabir & 1 & 395 & Ichneumia albicauda & Ichneumia albicauda \\
\hline Flaherty & 3 & 1,585 & Mustela erminea & Vulpes vulpes \\
\hline Fyn & 6 & 2,985 & Mustela erminea & Meles meles \\
\hline Galang & 2 & 74 & Aonyx cinerea & Arctogalidia trivirgata \\
\hline Gigha & 1 & 14 & Vulpes vulpes & Vulpes vulpes \\
\hline Gilford & 1 & 382 & Martes americana & Martes americana \\
\hline Gotland & 1 & 3,173 & Vulpes vulpes & Vulpes vulpes \\
\hline Graham & 4 & 6,361 & Mustela erminea & Ursus americanus \\
\hline Grand Manan & 1 & 137 & Vulpes vulpes & Vulpes vulpes \\
\hline Gravina & 2 & 233 & Martes americana & Ursus americanus \\
\hline Great Wass & 1 & 11 & Mustela vison & Mustela vison \\
\hline Gribble/Gribbell & 2 & 220 & Ursus americanus & Ursus americanus \\
\hline Guadaloupe & 1 & 1,510 & Procyon minor & Procyon minor \\
\hline
\end{tabular}


App. from S. Meiri et al., "Insular Carnivores and Optimal Size"

Table A2 (Continued)

\begin{tabular}{|c|c|c|c|c|}
\hline Island & $\begin{array}{l}\text { Carnivore } \\
\text { richness }\end{array}$ & $\begin{array}{l}\text { Area } \\
\left(\mathrm{km}^{2}\right)\end{array}$ & $\begin{array}{l}\text { Smallest } \\
\text { carnivore }\end{array}$ & $\begin{array}{c}\text { Largest } \\
\text { carnivore }\end{array}$ \\
\hline Guernsey & 1 & 64 & Mustela erminea & Mustela erminea \\
\hline Hainan & 14 & 33,940 & Mustela kathiah & Ursus thibetanus \\
\hline Halleck & 1 & 33 & Lontra canadensis & Lontra canadensis \\
\hline Hatia & 1 & 415.7 & Aonyx cinerea & Aonyx cinerea \\
\hline Hawkesbury & 3 & 365 & Martes americana & Ursus americanus \\
\hline Heceta & 3 & 189 & Mustela erminea & Ursus americanus \\
\hline Hiiumaa & 7 & 980 & Mustela nivalis & Ursus arctos \\
\hline Hinchinbrook & 4 & 442 & Mustela erminea & Ursus arctos \\
\hline Hokkaido & 10 & 77,978 & Mustela nivalis & Ursus arctos \\
\hline Hong Kong & 7 & 78 & Mustela kathiah & Vulpes vulpes \\
\hline Honshu & 11 & 227,898 & Mustela nivalis & Ursus thibetanus \\
\hline Hoste & 2 & 4,117 & Lontra provocax & Pseudalopex culpaeus \\
\hline Ibiza & 2 & 541 & Martes foina & Genetta genetta \\
\hline Ikaria & 2 & 263 & Martes foina & Canis aureus \\
\hline Iki & 1 & 135 & Mustela sibirica & Mustela sibirica \\
\hline Ios & 1 & 108 & Mustela nivalis & Mustela nivalis \\
\hline Ireland & 6 & 84,406 & Mustela erminea & Canis lupus \\
\hline Iriomote & 1 & 284 & Felis iriomotensis & Felis iriomotensis \\
\hline Islay & 2 & 622 & Mustela erminea & Lutra lutra \\
\hline Isle au Haut & 3 & 27 & Mustela vison & Lontra canadensis \\
\hline Ithaca & 1 & 95 & Martes foina & Martes foina \\
\hline Iturup & 5 & 3,200 & Mustela nivalis & Ursus arctos \\
\hline Java & 21 & 132,187 & Mustela sibirica & Panthera tigris \\
\hline Jersey & 1 & 117 & Mustela erminea & Mustela erminea \\
\hline Jura & 2 & 377 & Mustela erminea & Lutra lutra \\
\hline Kangean & 3 & 430 & Viverricula indica & Panthera pardus \\
\hline Karaginskij & 6 & 1,936 & Mustela erminea & Ursus arctos \\
\hline Karimata & 2 & 179 & Aonyx cinerea & Viverra tangalunga \\
\hline Karimon & 1 & 131 & Aonyx cinerea & Aonyx cinerea \\
\hline Karimunjawa & 2 & 18.3 & Aonyx cinerea & Felis bengalensis \\
\hline Karpathos & 1 & 280 & Martes foina & Martes foina \\
\hline Kayak & 2 & 77 & Vulpes vulpes & Ursus arctos \\
\hline Kefalonia & 5 & 775 & Mustela nivalis & Meles meles \\
\hline King & 1 & 808 & Mustela vison & Mustela vison \\
\hline Kinmen & 1 & 150 & Lutra lutra & Lutra lutra \\
\hline Kiska & 1 & 278 & Alopex lagopus & Alopex lagopus \\
\hline Kisseraing & 1 & 408 & Paradoxurus hermaphroditus & Paradoxurus hermaphroditus \\
\hline Kithira & 4 & 277 & Mustela nivalis & Meles meles \\
\hline Kodiak & 6 & 9,293 & Mustela erminea & Ursus arctos \\
\hline Koh Samui & 1 & 233 & Paradoxurus hermaphroditus & Paradoxurus hermaphroditus \\
\hline Koh Chang & 2 & 214.6 & Herpestes javanicus & Viverricula indica \\
\hline Koh yao & 2 & 100 & Paguma larvata & Paradoxurus hermaphroditus \\
\hline Korcula & 4 & 278 & Mustela nivalis & Canis aureus \\
\hline Kos & 2 & 287 & Martes foina & Vulpes vulpes \\
\hline Kosciusko & 2 & 482 & Canis lupus & Ursus americanus \\
\hline Krestof & 2 & 28 & Lontra canadensis & Ursus arctos \\
\hline Krk & 3 & 418.6 & Martes foina & Vulpes vulpes \\
\hline Kruzof & 4 & 447 & Mustela erminea & Ursus arctos \\
\hline Kuiu & 6 & 1,933 & Martes americana & Ursus americanus \\
\hline Kunashir & 5 & 1,490 & Mustela nivalis & Ursus arctos \\
\hline Kundur & 5 & 315 & Arctogalidia trivirgata & Arctictis binturong \\
\hline Kupreanof & 7 & 2,822 & Martes americana & Ursus americanus \\
\hline Kyushu & 8 & 36,719 & Mustela sibirica & Ursus thibetanus \\
\hline Lamukotan & 1 & 10 & Mydaus javanensis & Mydaus javanensis \\
\hline Langkawi & 4 & 363 & Arctogalidia trivirgata & Lutra perspicillata \\
\hline Lantau & 4 & 142 & Mustela kathiah & Lutra lutra \\
\hline Laut (Borneo) & 2 & 2,057 & Aonyx cinerea & Viverra tangalunga \\
\hline Laut (Natuna) & 3 & 33 & Aonyx cinerea & Viverra tangalunga \\
\hline Lefkada & 4 & 279 & Mustela nivalis & Canis aureus \\
\hline Lesbos & 5 & 1,630 & Mustela nivalis & Meles meles \\
\hline
\end{tabular}


App. from S. Meiri et al., "Insular Carnivores and Optimal Size"

Table A2 (Continued)

\begin{tabular}{|c|c|c|c|c|}
\hline Island & $\begin{array}{l}\text { Carnivore } \\
\text { richness }\end{array}$ & $\begin{array}{l}\text { Area } \\
\left(\mathrm{km}^{2}\right)\end{array}$ & $\begin{array}{l}\text { Smallest } \\
\text { carnivore }\end{array}$ & $\begin{array}{c}\text { Largest } \\
\text { carnivore }\end{array}$ \\
\hline Lewis & 1 & 2,137 & Lutra lutra & Lutra lutra \\
\hline Leyte & 2 & 7,213 & Paradoxurus hermaphroditus & Viverra tangalunga \\
\hline Lingga & 3 & 889 & Aonyx cinerea & Viverra tangalunga \\
\hline Lolland & 4 & 1,243 & Mustela nivalis & Vulpes vulpes \\
\hline Lombok & 2 & 4,725 & Paradoxurus hermaphroditus & Felis bengalensis \\
\hline Long (Maine) & 2 & 24 & Mustela vison & Vulpes vulpes \\
\hline \multicolumn{5}{|l|}{ Long (Alexander } \\
\hline Archipelago) & 3 & 115 & Mustela erminea & Lontra canadensis \\
\hline Louise & 4 & 275 & Mustela erminea & Ursus americanus \\
\hline Luzon & 2 & 104,688 & Paradoxurus hermaphroditus & Viverra tangalunga \\
\hline Lyo & 1 & 6 & Mustela erminea & Mustela erminea \\
\hline Madagascar & 8 & 587,041 & Galidictis fasciata & Cryptoprocta ferox \\
\hline Madura & 3 & 4,560 & Herpestes javanicus & Panthera pardus \\
\hline Magdalena & 1 & 290 & Canis latrans & Canis latrans \\
\hline Majorca & 4 & 3,640 & Mustela nivalis & Felis silvestris \\
\hline Malta & 1 & 246 & Mustela nivalis & Mustela nivalis \\
\hline Man & 2 & 572 & Mustela erminea & Lutra lutra \\
\hline Marble & 1 & 23 & Lontra canadensis & Lontra canadensis \\
\hline Margarita & 2 & 957 & Conepatus semistriatus & Felis pardalis \\
\hline Maria Madre & 1 & 200 & Procyon insularis & Procyon insularis \\
\hline Maria Magdalena & 1 & 150 & Procyon insularis & Procyon insularis \\
\hline Marinduque & 1 & 958 & Paradoxurus hermaphroditus & Paradoxurus hermaphroditus \\
\hline Maripipi & 1 & 22 & Paradoxurus hermaphroditus & Paradoxurus hermaphroditus \\
\hline Mindanao & 2 & 94,631 & Paradoxurus hermaphroditus & Viverra tangalunga \\
\hline Mindoro & 2 & 9,735 & Paradoxurus hermaphroditus & Viverra tangalunga \\
\hline Minorca & 2 & 702 & Mustela nivalis & Martes martes \\
\hline Mitkof & 7 & 547 & Mustela erminea & Ursus americanus \\
\hline Mljet & 1 & 104 & Martes foina & Martes foina \\
\hline Montague & 2 & 850 & Lontra canadensis & Ursus arctos \\
\hline Moresby & 3 & 2,636 & Mustela erminea & Lontra canadensis \\
\hline Mount Desert & 11 & 275 & Mustela erminea & Ursus americanus \\
\hline Mull & 4 & 909 & Mustela erminea & Lutra lutra \\
\hline Nagai & 1 & 310 & Lontra canadensis & Lontra canadensis \\
\hline Naxos & 2 & 436 & Mustela nivalis & Martes foina \\
\hline Negros & 3 & 13,670 & Paradoxurus hermaphroditus & Viverra tangalunga \\
\hline Newfoundland & 10 & 108,860 & Mustela erminea & Ursus americanus \\
\hline Nias & 2 & 4,600 & Felis bengalensis & Arctictis binturong \\
\hline Nootka & 4 & 529 & Mustela vison & Ursus americanus \\
\hline North Pagai & 1 & 530 & Paradoxurus hermaphroditus & Paradoxurus hermaphroditus \\
\hline North Twin & 1 & 157 & Alopex lagopus & Alopex lagopus \\
\hline North Uist & 1 & 294 & Lutra lutra & Lutra lutra \\
\hline Nunivak & 2 & 4,209 & Mustela vison & Alopex lagopus \\
\hline Nusa Barung & 1 & 1 & Viverricula indica & Viverricula indica \\
\hline Oki & 1 & 262.8 & Nyctereutes procyonoides & Nyctereutes procyonoides \\
\hline Oland & 6 & 1,351 & Mustela nivalis & Meles meles \\
\hline Orcas & 1 & 143 & Lontra canadensis & Lontra canadensis \\
\hline Orkney & 2 & 490 & Mustela erminea & Lutra lutra \\
\hline Padang & 2 & 1,109 & Paradoxurus hermaphroditus & Ursus malayanus \\
\hline Padre & 5 & 119 & Procyon lotor & Canis rufus \\
\hline Palawan & 9 & 11,785 & Felis planiceps & Arctictis binturong \\
\hline Panaitan & 5 & 118 & Herpestes javanicus & Panthera pardus \\
\hline Panay & 3 & 12,300 & Paradoxurus hermaphroditus & Viverra tangalunga \\
\hline Panebangan & 1 & 26 & Viverra tangalunga & Viverra tangalunga \\
\hline Paramushir & 4 & 2,053 & Mustela nivalis & Ursus arctos \\
\hline Parida & 1 & 15 & Potos flavus & Potos flavus \\
\hline Pemba & 1 & 984 & Atilax paludinosus & Atilax paludinosus \\
\hline Pender & 1 & 26 & Procyon lotor & Procyon lotor \\
\hline Pinang & 5 & 293 & Viverricula indica & Viverra megaspila \\
\hline Pini & 1 & 313 & Arctogalidia trivirgata & Arctogalidia trivirgata \\
\hline Pitt & 4 & 1,349 & Martes americana & Ursus americanus \\
\hline
\end{tabular}


App. from S. Meiri et al., "Insular Carnivores and Optimal Size"

Table A2 (Continued)

\begin{tabular}{|c|c|c|c|c|}
\hline Island & $\begin{array}{l}\text { Carnivore } \\
\text { richness }\end{array}$ & $\begin{array}{l}\text { Area } \\
\left(\mathrm{km}^{2}\right)\end{array}$ & $\begin{array}{l}\text { Smallest } \\
\text { carnivore }\end{array}$ & $\begin{array}{l}\text { Largest } \\
\text { carnivore }\end{array}$ \\
\hline Polillo & 1 & 769 & Viverra tangalunga & Viverra tangalunga \\
\hline Popa & 2 & 53 & Potos flavus & Procyon lotor \\
\hline Porcher & 4 & 521 & Mustela erminea & Canis lupus \\
\hline Price & 1 & 171 & Mustela vison & Mustela vison \\
\hline Prince Edward & 11 & 5,657 & Mustela erminea & Ursus americanus \\
\hline Prince of Wales & 6 & 6,675 & Mustela erminea & Ursus americanus \\
\hline Princess Royal & 2 & 2,355 & Canis lupus & Ursus americanus \\
\hline Qeshm & 4 & 1,488 & Herpestes javanicus & Felis silvestris \\
\hline Quadra & 2 & 270 & Canis lupus & Felis concolor \\
\hline Raasey & 2 & 60 & Vulpes vulpes & Lutra lutra \\
\hline $\mathrm{Rab}$ & 2 & 90.8 & Mustela nivalis & Martes foina \\
\hline Read & 5 & 407.7 & Mustela erminea & Ursus americanus \\
\hline Revillagigedo & 6 & 3,024 & Mustela erminea & Ursus americanus \\
\hline Rhodes & 4 & 1,398 & Mustela nivalis & Meles meles \\
\hline Rhum & 1 & 110 & Lutra lutra & Lutra lutra \\
\hline Rishiri & 2 & 192 & Mustela sibirica & Vulpes vulpes \\
\hline Rugen & 1 & 926 & Vulpes vulpes & Vulpes vulpes \\
\hline Rupat & 3 & 1,490 & Paradoxurus hermaphroditus & Ursus malayanus \\
\hline Saaremaa & 10 & 2,673 & Mustela nivalis & Ursus arctos \\
\hline Sado Shima & 2 & 937 & Mustela sibirica & Nyctereutes procyonoides \\
\hline Saint Lawrence & 4 & 5,135 & Alopex lagopus & Ursus arctos \\
\hline \multicolumn{5}{|l|}{ Saint Matthew (Mergui } \\
\hline Archipelago) & 1 & 176 & Paradoxurus hermaphroditus & Paradoxurus hermaphroditus \\
\hline Saint Matthew (Alaska) & 1 & 354 & Alopex lagopus & Alopex lagopus \\
\hline Saint Paul (Pribilof) & 1 & 91 & Vulpes vulpes & Vulpes vulpes \\
\hline Sakhalin & 11 & 76,400 & Mustela nivalis & Ursus arctos \\
\hline Saltspring & 3 & 187 & Mustela erminea & Felis concolor \\
\hline Samar & 1 & 13,429 & Viverra tangalunga & Viverra tangalunga \\
\hline Samos & 3 & 159 & Mustela nivalis & Canis aureus \\
\hline Alonisos & 1 & 64.0 & Martes foina & Martes foina \\
\hline Samothraki (Samothrace) & 1 & 183.8 & Martes foina & Martes foina \\
\hline San Clemente & 1 & 152 & Urocyon littoralis & Urocyon littoralis \\
\hline San Cristobal & 2 & 37 & Potos flavus & Procyon lotor \\
\hline San Jose & 1 & 165 & Bassariscus astutus & Bassariscus astutus \\
\hline San Miguel & 2 & 36 & Spilogale gracilis & Urocyon littoralis \\
\hline San Nicholas & 1 & 57 & Urocyon littoralis & Urocyon littoralis \\
\hline Sanga-Sanga & 1 & 67.1 & Paradoxurus hermaphroditus & Paradoxurus hermaphroditus \\
\hline Sanibel & 1 & 45 & Procyon lotor & Procyon lotor \\
\hline Santa Catalina & 1 & 193 & Urocyon littoralis & Urocyon littoralis \\
\hline Santa Cruz & 2 & 249 & Spilogale gracilis & Urocyon littoralis \\
\hline Santa Rosa & 2 & 215 & Spilogale gracilis & Urocyon littoralis \\
\hline Sardinia & 4 & 23,813 & Mustela nivalis & Vulpes vulpes \\
\hline Sebangka & 1 & 120 & Aonyx cinerea & Aonyx cinerea \\
\hline Seguam & 1 & 215 & Alopex lagopus & Alopex lagopus \\
\hline Setoko & 2 & 17 & Aonyx cinerea & Panthera tigris \\
\hline Shantar & 4 & 1,766 & Mustela erminea & Ursus arctos \\
\hline Sheppey & 3 & 91 & Mustela nivalis & Meles meles \\
\hline Shetland & 1 & 899 & Lutra lutra & Lutra lutra \\
\hline Shikoku & 9 & 18,292 & Mustela sibirica & Ursus thibetanus \\
\hline Shrubby & 2 & 15 & Mustela vison & Lontra canadensis \\
\hline Shumshu & 4 & 388 & Mustela nivalis & Ursus arctos \\
\hline Shuyak & 2 & 168 & Lontra canadensis & Ursus arctos \\
\hline Siberut & 2 & 3,829 & Hemigalus derbyanus & Paradoxurus lignicolor \\
\hline Sibuyan & 2 & 465 & Paradoxurus hermaphroditus & Viverra tangalunga \\
\hline Sicily & 7 & 25,460 & Mustela nivalis & Canis lupus \\
\hline Sidney & 1 & 9 & Mustela vison & Mustela vison \\
\hline Siguijor & 1 & 334 & Viverra tangalunga & Viverra tangalunga \\
\hline Simeulue & 1 & 1,754 & Paradoxurus hermaphroditus & Paradoxurus hermaphroditus \\
\hline Singapore & 19 & 536 & Viverricula indica & Panthera tigris \\
\hline Singkep & 1 & 175 & Arctogalidia trivirgata & Arctogalidia trivirgata \\
\hline
\end{tabular}


App. from S. Meiri et al., "Insular Carnivores and Optimal Size"

Table A2 (Continued)

\begin{tabular}{|c|c|c|c|c|}
\hline Island & $\begin{array}{l}\text { Carnivore } \\
\text { richness }\end{array}$ & $\begin{array}{l}\text { Area } \\
\left(\mathrm{km}^{2}\right)\end{array}$ & $\begin{array}{l}\text { Smallest } \\
\text { carnivore }\end{array}$ & $\begin{array}{l}\text { Largest } \\
\text { carnivore }\end{array}$ \\
\hline Sipora & 2 & 840 & Hemigalus derbyanus & Paradoxurus hermaphroditus \\
\hline Sjaelland & 7 & 7,031 & Mustela nivalis & Lutra lutra \\
\hline Skaro & 1 & 2 & Mustela erminea & Mustela erminea \\
\hline Skye & 5 & 1,735 & Mustela nivalis & Lutra lutra \\
\hline South Pagai & 2 & 1,410 & Hemigalus derbyanus & Paradoxurus hermaphroditus \\
\hline South Twin & 1 & 150 & Alopex lagopus & Alopex lagopus \\
\hline South Uist & 1 & 365 & Lutra lutra & Lutra lutra \\
\hline Sri Lanka & 14 & 65,000 & Felis rubiginosus & Ursus ursinus \\
\hline Suemez & 3 & 153 & Mustela erminea & Canis lupus \\
\hline Sugi & 1 & 89.9 & Arctogalidia trivirgata & Arctogalidia trivirgata \\
\hline Sullivan & 1 & 188 & Paradoxurus hermaphroditus & Paradoxurus hermaphroditus \\
\hline Sumatra & 30 & 473,607 & Mustela lutreolina & Panthera tigris \\
\hline Swans & 1 & 28 & Mustela vison & Mustela vison \\
\hline Taiwan & 14 & 35,989 & Mustela sibirica & Ursus thibetanus \\
\hline Tanegashima & 1 & 456 & Mustela sibirica & Mustela sibirica \\
\hline Tebing Tinggi & 3 & 1,598 & Arctogalidia trivirgata & Arctictis binturong \\
\hline Telebon & 1 & 33 & Paradoxurus hermaphroditus & Paradoxurus hermaphroditus \\
\hline Terutao & 2 & 152 & Arctogalidia trivirgata & Paradoxurus hermaphroditus \\
\hline Thasos & 2 & 300 & Martes foina & Canis aureus \\
\hline Tiburon & 3 & 1,212 & Bassariscus astutus & Canis latrans \\
\hline Tierra del Fuego & 6 & 73,746 & Conepatus humboldti & Felis concolor \\
\hline Tioman & 3 & 140 & Arctogalidia trivirgata & Arctictis binturong \\
\hline Tobago & 1 & 300 & Procyon cancrivorus & Procyon cancrivorus \\
\hline Trinidad & 4 & 4,828 & Eira barbara & Felis pardalis \\
\hline Tukarak & 3 & 349 & Mustela erminea & Vulpes vulpes \\
\hline Tuxekan & 1 & 85 & Ursus americanus & Ursus americanus \\
\hline Umnak & 1 & 1,793 & Vulpes vulpes & Vulpes vulpes \\
\hline Unalaska & 2 & 2,722 & Mustela erminea & Vulpes vulpes \\
\hline Unimak & 8 & 4,119 & Mustela nivalis & Ursus arctos \\
\hline Urup & 1 & 1,450 & Vulpes vulpes & Vulpes vulpes \\
\hline Vancouver & 9 & 31,285 & Mustela erminea & Ursus americanus \\
\hline Vargas & 1 & 28 & Mustela vison & Mustela vison \\
\hline Vinal Haven & 3 & 52 & Mustela vison & Lontra canadensis \\
\hline Warren & 2 & 50 & Lontra canadensis & Canis lupus \\
\hline Wetar & 1 & 445 & Paradoxurus hermaphroditus & Paradoxurus hermaphroditus \\
\hline Whidby & 1 & 445 & Mustela erminea & Mustela erminea \\
\hline Wight & 5 & 392 & Mustela nivalis & Meles meles \\
\hline Woewodski & 2 & 41 & Martes americana & Canis lupus \\
\hline Wolin & 3 & 246 & Martes martes & Meles meles \\
\hline Woronkofski & 1 & 60 & Lontra canadensis & Lontra canadensis \\
\hline Wrangel & 8 & 569 & Mustela erminea & Ursus americanus \\
\hline Serifos & 1 & 73 & Martes foina & Martes foina \\
\hline Kythnos & 1 & 102 & Martes foina & Martes foina \\
\hline Skopelos & 2 & 90 & Mustela nivalis & Martes foina \\
\hline Tinos & 1 & 193 & Meles meles & Meles meles \\
\hline Thera (Santoríni) & 2 & 76 & Mustela nivalis & Martes foina \\
\hline Yakushima & 1 & 524 & Mustela sibirica & Mustela sibirica \\
\hline Zakynthos & 2 & 419 & Mustela nivalis & Martes foina \\
\hline Zanzibar & 5 & 1,651 & Galerella sanguinea & Panthera pardus \\
\hline Zarembo & 4 & 472 & Mustela erminea & Ursus americanus \\
\hline
\end{tabular}

